I NTER N A T I ONAL MONETARY FUND African Department

\title{
Central African Economic \\ and Monetary Community
}

A New Medium-Term Approach for International Reserve Management

Mario de Zamaróczy, Vincent Fleuriet, and José Gijón

No. $18 / 15$ 


\section{Central African Economic and Monetary Community A New Medium-Term Approach for International Reserve Management}

Mario de Zamaróczy, Vincent Fleuriet, and José Gijón 
Copyright @2018 International Monetary Fund

\title{
Cataloging-in-Publication Data
}

\author{
Joint Bank-Fund Library
}

Names: Zamaróczy, Mario de. | Fleuriet, Vincent. | Gijón-Spalla, José G. | International Monetary Fund. Title: Central African Economic and Monetary Community : a new medium term approaclfor international reserve management / Mario de Zamaróczy, Vincent Fleuriet, and José Gijón.

Other titles: CEMAC : a new medium term approachfor international reserve management | Communauté économique et monétaire de l'Afrique centrale : a new medium term approach for international reserve management | International Monetary Fund. African Department (Series)

Description: Washington, DC : International Monetary Fund, [2018] || Includes bibliographical references. | At head of title: The African Department. | Departmental paper series. Identifiers: ISBN 9781484350676 (paper)

Subjects: LCSH: Foreign exchange reserves—Africa, Central. | Bank reserves-Africa, Central. | Petroleum industry and trade-Africa, Central. | Communauté économique et monétaire de l'Afrique centrale. Classification: LCC HG3853.4 .C44 2018

The Departmental Paper Series presents research by IMF staff on issues of broad regional or cross-country interest. The views expressed in this paper are those of the author(s) and do not necessarily represent the views of the IMF, its Executive Board, or IMF management.

Publication orders may be placed online, by fax, or through the mail: International Monetary Fund, Publication Services P.O. Box 92780, Washington, DC 20090, U.S.A.

Tel. (202) 623-7430 Fax: (202) 623-7201

E-mail: publications@imf.org www.imfbookstore.org www.elibrary.imf.org 


\section{Contents}

Acknowledgments...................................................................................................v

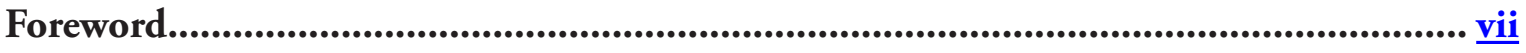

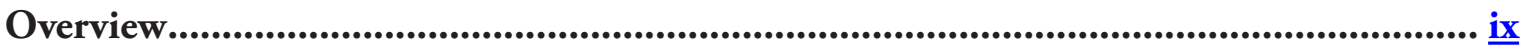

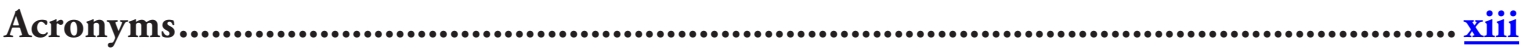

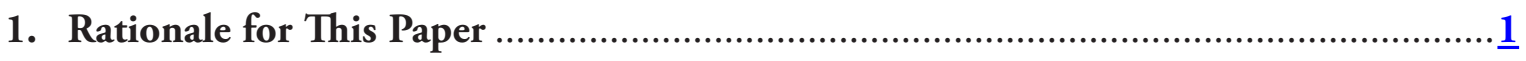

2. Economic and Institutional Context.............................................................. $\underline{3}$

3. CEMAC's International Reserve Adequacy ............................................................... 9

4. International Reserves and Fiscal Rules ............................................................ 17

5. Recommendations for a New Reserve Management Framework............................. 21

6. Considerations for Reserve Management............................................................. 29

7. Conclusion................................................................................................................ $\underline{33}$

Annex 1. International Reserves in a Currency Union.................................................... $\underline{35}$

Annex 2. Does CEMAC Need Pooled International Reserves?....................................... 37

Annex 3. CEMAC: Foreign Exchange Transaction and Payment Arrangements............ $\underline{39}$

Annex 4. Surrender Requirements in Currency Unions................................................... $\underline{41}$

Annex 5. BEAC's International Reserve Management Framework............................... $\underline{43}$

Annex 6. International Reserve Adequacy in Currency Unions ................................... $\underline{45}$

Annex 7. International Reserves and Fiscal Policy....................................................... $\underline{47}$

Figures

1. CEMAC: Oil Production, 1980-2030 …............................................................

2. CEMAC: Gross International Reserves, 2000-16...............................................

3. CEMAC: Member States' Reserves by Domicile, 2007-16 ......................................11

4. CEMAC: International Reserve Assets Import Coverage, 2001-21 .......................... 13

5. CEMAC: Model-Based Recommended Optimal Reserves, 2016...............................

6. BEAC: Government Deposits and International Reserves, 2000-16 ......................... 18

7. CEMAC: Fiscal Stances, 2000-16 ....................................................................

8. CEMAC: Average Equilibrium Price per Barrel of Oil, 2008-16 .............................20 


\section{Tables}

1. CEMAC: Relative Size of Economies and Importance of the Oil Sector, 2013-16 .... $\underline{5}$

2. CEMAC: Selected Partners' Trade Shares, 1995-2015 ...............................................

3. CEMAC: Reserve Adequacy Indicators, 2011-16 ............................................... 14

4. BEAC: Simplified Balance Sheet, 2015-16 .........................................................

Annex Table 4.1. Repatriation and Surrender Requirements in Currency Unions ......... $\underline{42}$

Annex Table 6.1. Selected Reserve Adequacy Benchmarks......................................... $\underline{46}$

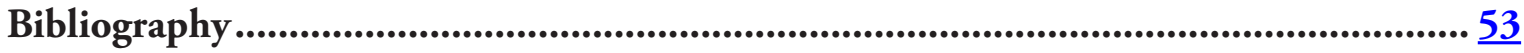




\section{Acknowledgments}

The authors express their gratitude for valuable comments received from Anne-Marie Gulde-Wolf, Guy Jenkinson, Nkunde Mwase, and David Stenzel. They also thank Azanaw Mengistu for excellent analytical support and Jean Vibar and Joanna Delcambre for excellent administrative support. This paper builds on an earlier version. The authors gratefully acknowledge contributions and comments to that version by Jitendra Bissessur, Alain Féler, Félix Fischer, Mumtaz Husain, Natalia Koliadina, Mesmin Koulet-Vickot, Liam O’Sullivan, Ivohasina Razafimahefa, Joël Toujas-Bernaté, Juan Trevino, Jean van Houtte, Bruno Versailles, Mauricio Villafuerte, Kal Wajid, Boriana Yontcheva, and Prosper Youm. Any errors are the sole responsibility of the authors. 
This page intentionally left blank

CInternational Monetary Fund. Not for Redistribution 


\section{Foreword}

The purpose of this paper is to foster a discussion on possible reserve management approaches in the Central African Economic and Monetary Community (CEMAC). The paper is published at a time when CEMAC is confronting a Community-wide economic crisis, stemming from, among other factors, the slump in international oil prices that began in the second half of 2014. Crude oil exports are CEMAC's largest foreign exchange source. Therefore, the decline in oil proceeds has adversely affected CEMAC's economic performance and its international reserves, which are pooled at the Community's common central bank. The ongoing crisis has brought several weaknesses to the fore in the Community's foreign exchange pooling practices and the central bank's international reserve management, hence the rationale for this paper.

This paper looks beyond the current crisis and proposes a new approach to international reserve management in the medium term. Accordingly, the approach advocated in this paper supposes that the current crisis has been surmounted. It assumes CEMAC has stabilized its economy and has successfully embarked on building adequate and sustainable buffers to withstand inevitable future crises, based on lessons distilled from the current crisis.

Because of its medium-term horizon, this paper has no relevance to policies for mitigating the ongoing crisis, nor to CEMAC member countries' discussions with stakeholders on possible reform programs, possibly supported by external financial assistance. Similarly, the paper has no relevance to ongoing reform efforts at the central bank to strengthen safeguards. 
This page intentionally left blank

CInternational Monetary Fund. Not for Redistribution 


\section{Overview}

A fundamental tenet of the Central African Economic and Monetary Community (CEMAC) is the pooling of member countries' international reserves at the regional central bank (BEAC). However, a sizable-albeit dwindlingportion of member governments' foreign currency assets have been held outside the Community. Accordingly, consideration has been given to reforming the BEAC's international reserve management framework based on the evolving needs of its member states.

Reform of the reserve management framework has become necessary in the wake of the oil-price shock. The oil-price slump, which started in the second half of 2014, has resulted in a marked deterioration in CEMAC's economic performance and outlook. The strong terms-of-trade shock has resulted in substantially lower foreign exchange inflows and fiscal revenues in CEMAC's five oil-producing countries. The weakening of their external positions increases the impact of noncompliance with the reserve pooling requirement and heightens risks of macroeconomic instability. The paper therefore proposes measures to reform and strengthen the current reserve management system.

CEMAC's international reserves grew 18-fold in 2001-13. They increased as a result of the buoyancy of foreign exchange earnings stemming from increased oil production and high oil prices. The oil-price shock, however, has led to a fundamental change in the medium-term outlook, which underscores the need for CEMAC countries to comply with the Community's reserve pooling requirement. Partial compliance and extensive use of statutory advances, combined with the decline in reserves, have hindered the capacity of the BEAC to 
conduct appropriate monetary and exchange rate policies and to sustain the common currency's pegged exchange rate to the euro.

The paper recommends that CEMAC adopt a target of five months of import coverage of goods and services for its pooled reserves. Member states' macroeconomic frameworks should be adapted to ensure consistency with sustaining this target. Accordingly, countries relying on oil proceeds, as their major source of fiscal revenue, need to accumulate sufficient buffers to mitigate the volatility in oil prices. In this regard, the paper recommends that CEMAC consider strengthening its fiscal rules to ensure that such buffers are put in place.

Against this background, the paper proposes a new reserve management framework based on two pillars:

- The first pillar comprises a common pool of foreign exchange reserves for exchange rate management and balance of payments purposes. Such reserves should be sufficient to (1) provide confidence to markets regarding the BEAC's ability to meet external obligations and to defend the peg, and (2) withstand an adverse external shock while mitigating policies are put in place. To ensure that such a reserve pool is adequately constituted, each member state would surrender its foreign currency proceeds to the BEAC, in line with existing rules, until it has provided sufficient foreign currency to cover five months of its imports on a continuous basis.

- The second pillar is designed to manage windfall revenues, that is, foreign exchange earnings above the target threshold of five months of CEMAC import coverage. Once the threshold is reached, member states would be free to deposit their excess foreign exchange earnings in stabilization funds. These funds could comprise less liquid and higher-yielding investment assets. Each member state would have its own stabilization fund-to be managed by the BEAC—-for meeting its own objectives and other considerations discussed in the paper.

Clear replenishment rules for pooled reserves need to be established. A mechanism will need to be designed to ensure that stabilization funds would support BEAC's pooled reserves in the first pillar in the event that these reserves fall below the targeted threshold of import coverage. A shortfall in reserve adequacy that arises because of an inappropriate macroeconomic policy stance in one or several member countries should trigger an adjustment process.

Once CEMAC member states adopt the general principles of the revised framework, further work will be needed to design detailed implementation rules and procedures. This process may require legal amendments to the BEAC's current rules and regulations, a clear definition of respective responsi- 
bilities between the BEAC and member countries, the design of a monitoring system, and the strengthening of reporting arrangements. In any event, continued improvements in the BEAC's operations, accompanied by increased transparency by member countries (in particular with regard to their foreign asset holdings), will be critical to the success of the proposed framework. 
This page intentionally left blank

CInternational Monetary Fund. Not for Redistribution 


\section{Acronyms}

$\begin{array}{ll}\text { AFR } & \text { African Department of the IMF } \\ \text { BCEAO } & \begin{array}{l}\text { Banque centrale des États de l'Afrique de l'Ouest (Central } \\ \text { Bank of West African States) }\end{array} \\ \text { BEAC } & \begin{array}{l}\text { Banque des États de l'Afrique centrale (Central Bank of } \\ \text { Central African States) }\end{array} \\ \text { CEMAC } & \begin{array}{l}\text { Communauté économique et monétaire de l'Afrique centrale } \\ \text { (Central African Economic and Monetary Community) }\end{array} \\ \text { CFAF } & \text { Communauté Financière Africaine Franc (CFA franc; African } \\ \text { ECCU } & \text { Financial Community Franc) Ac } \\ \text { GDP } & \text { Eastern Caribbean Currency Union } \\ \text { IMF } & \text { gross domestic product } \\ \text { NSF } & \text { national stabilization fund } \\ \text { NRPB } & \text { non-resource primary balance } \\ \text { PIH } & \text { permanent income hypothesis } \\ \text { SDR } & \text { Special Drawing Right } \\ \text { US\$ } & \text { United States dollar } \\ \text { WAEMU } & \text { West African Economic and Monetary Union } \\ \text { WEO } & \text { World Economic Outlook }\end{array}$

xiii 
This page intentionally left blank

CInternational Monetary Fund. Not for Redistribution 


\section{ChAPTER}

\section{Rationale for This Paper}

Several Central African Economic and Monetary Community (CEMAC) member countries accumulated large foreign currency balances in a context of high oil prices in 2001-13. ${ }^{1}$ Under CEMAC's current arrangements, these savings are to be deposited with the regional central bank (BEAC) in exchange for local currency. ${ }^{2}$ Yet, a significant-albeit dwindling - portion of member governments' foreign currency assets are not held by the BEAC. This practice breaches the requirement for all CEMAC residents, including all public entities, to surrender their foreign currency assets to the BEAC. ${ }^{3}$ The CEMAC member governments that maintain a portion of their foreign currency assets outside the BEAC are mainly those with large oil-export receipts.

The impact of noncompliance with reserve pooling provisions has been aggravated by the deterioration in CEMAC's external position following the slump in oil prices. Against this background, consideration has been given to reforming CEMAC's international reserve management framework, based on the evolving needs of its members. The BEAC set up an ad hoc working group and called on the International Monetary Fund (IMF) to suggest ways to reform its framework. ${ }^{4}$

This paper proposes a new framework and measures for strengthening CEMAC's reserve management. ${ }^{5}$ Section 2 describes CEMAC's economic and institutional context. Section 3 assesses CEMAC's international reserve

${ }^{1}$ CEMAC stands for Communauté Économique et Monétaire de l'Afrique Centrale.

${ }^{2} \mathrm{BEAC}$ stands for Banque des États de l'Afrique Centrale.

${ }^{3}$ Foreign currency earnings surrendered to the BEAC are converted into local currency deposits. In turn, the BEAC provides the foreign exchange needed for legal international transactions against domestic currency.

${ }^{4}$ The group is called the Comité Mixte sur le Rapatriement des Avoirs en Devises des États Membres de la CEMAC (Joint Committee on the Repatriation of CEMAC Member States' Foreign Currency Assets).

${ }^{5}$ Questions on whether (1) CEMAC forms an optimal currency union, (2) individual CEMAC member states should be members of the currency union, (3) the current peg of the CFA franc to the euro is the most 
adequacy. Section 4 discusses links between international reserves and fiscal rules. Section 5 proposes a new reserve management framework. Section 6 discusses considerations linked to the implementation of the proposed framework. Section 7 presents conclusions.

appropriate exchange rate regime for CEMAC, and (4) investing part of the BEAC's foreign reserves with the French Treasury is worthwhile are beyond the scope of this paper. 


\section{Chapter}

\section{Economic and Institutional Context}

\section{Key Features of CEMAC's External Sector}

CEMAC economies rely heavily on oil, which is their main export commodity (Table 1 and Figure 1). ${ }^{1}$ In 2013, the year before the oil-price slump started, oil accounted for 32 percent of regional GDP, 84 percent of merchandise exports, and 60 percent of fiscal revenue. CEMAC has two groups, one comprising four countries with substantial net oil exports (Equatorial Guinea, the Republic of Congo, Gabon, and Chad in declining order of the current share of oil exports in regional exports) and another group comprising one country with limited oil exports (Cameroon) and one with no oil exports (Central African Republic).

In recent years, CEMAC's trade has partly shifted from the euro area toward emerging markets (Table 2). Although the European Union still accounted for about 27 percent of CEMAC's trade in 2015, its share had been generally declining, while the share of developing Asia rose from 3 percent in 1995 to 32 percent in 2015 . Intraregional trade accounted for about $1 \frac{1 / 4}{4}$ percent of CEMAC's total trade in 2015.

CEMAC's external public debt has been rising rapidly following debt relief. Cameroon, Central African Republic, and the Republic of Congo benefited from substantial debt relief after reaching their Highly-Indebted Poor Country completion points. Gabon's debt profile improved significantly following a 2007 debt restructuring. Chad also improved its debt profile after receiving debt relief of US\$1.1 billion in April 2015. At the end of 2016, CEMAC's external public debt was equivalent to 23 percent of regional GDP. However,

${ }^{1}$ CEMAC comprises Cameroon, the Central African Republic, Chad, the Republic of Congo, Equatorial Guinea, and Gabon. 
Table 1. CEMAC: Relative Size of Economies and Importance of Oil Sector, 2013-16 (Percent of GDP)

\begin{tabular}{|c|c|c|c|c|c|c|}
\hline & $\begin{array}{l}\text { Country GDP/ } \\
\text { CEMAC's GDP }\end{array}$ & $\begin{array}{l}\text { Country Oil GDP/ } \\
\text { CEMAC's GDP }\end{array}$ & $\begin{array}{l}\text { Country Oil GDP/ } \\
\text { Country GDP }\end{array}$ & $\begin{array}{c}\text { Country Oil Exports/ } \\
\text { Country Merchandise } \\
\text { Exports }\end{array}$ & $\begin{array}{c}\text { Country Fiscal } \\
\text { Oil Revenue/ } \\
\text { Country Fiscal } \\
\text { Revenue }\end{array}$ & $\begin{array}{l}\text { Country External } \\
\text { Trade Balance/ } \\
\text { Country GDP }\end{array}$ \\
\hline & \multicolumn{6}{|c|}{2013} \\
\hline Cameroon & 32.6 & 2.3 & 7.2 & 50.9 & 27.2 & -2.8 \\
\hline Central African Republic & 1.7 & 0.0 & 0.0 & 0.0 & 0.0 & -11.6 \\
\hline Chad & 14.8 & 4.0 & 27.1 & 82.8 & 63.4 & -10.0 \\
\hline Congo, Republic of & 14.8 & 8.6 & 58.0 & 86.4 & 74.1 & 16.7 \\
\hline Equatorial Guinea & 17.2 & 9.5 & 55.3 & 99.4 & 68.5 & 19.8 \\
\hline Gabon & 19.0 & 7.1 & 37.6 & 80.5 & 51.3 & 30.0 \\
\hline \multirow[t]{2}{*}{ CEMAC } & 100.0 & 31.7 & 31.7 & 83.6 & 60.3 & 8.9 \\
\hline & \multicolumn{6}{|c|}{2016} \\
\hline Cameroon & 39.1 & 1.6 & 4.0 & 28.5 & 15.0 & -2.6 \\
\hline Central African Republic & 2.3 & 0.0 & 0.0 & 0.0 & 0.0 & -16.9 \\
\hline Chad & 13.5 & 2.6 & 19.2 & 73.3 & 24.4 & -15.5 \\
\hline Congo, Republic of & 10.6 & 3.8 & 36.2 & 80.1 & 32.5 & -19.5 \\
\hline Equatorial Guinea & 15.5 & 3.6 & 23.0 & 87.5 & 72.9 & 6.4 \\
\hline Gabon & 19.0 & 5.4 & 28.4 & 72.4 & 29.3 & 0.3 \\
\hline CEMAC & 100.0 & 17.0 & 17.0 & 68.6 & 18.3 & -4.5 \\
\hline
\end{tabular}

Sources: CEMAC authorities; and IMF staff estimates.

Note: $\mathrm{CEMAC}=$ Central African Economic and Monetary Community 
Figure 1. CEMAC: Oil Production, 1980-2030

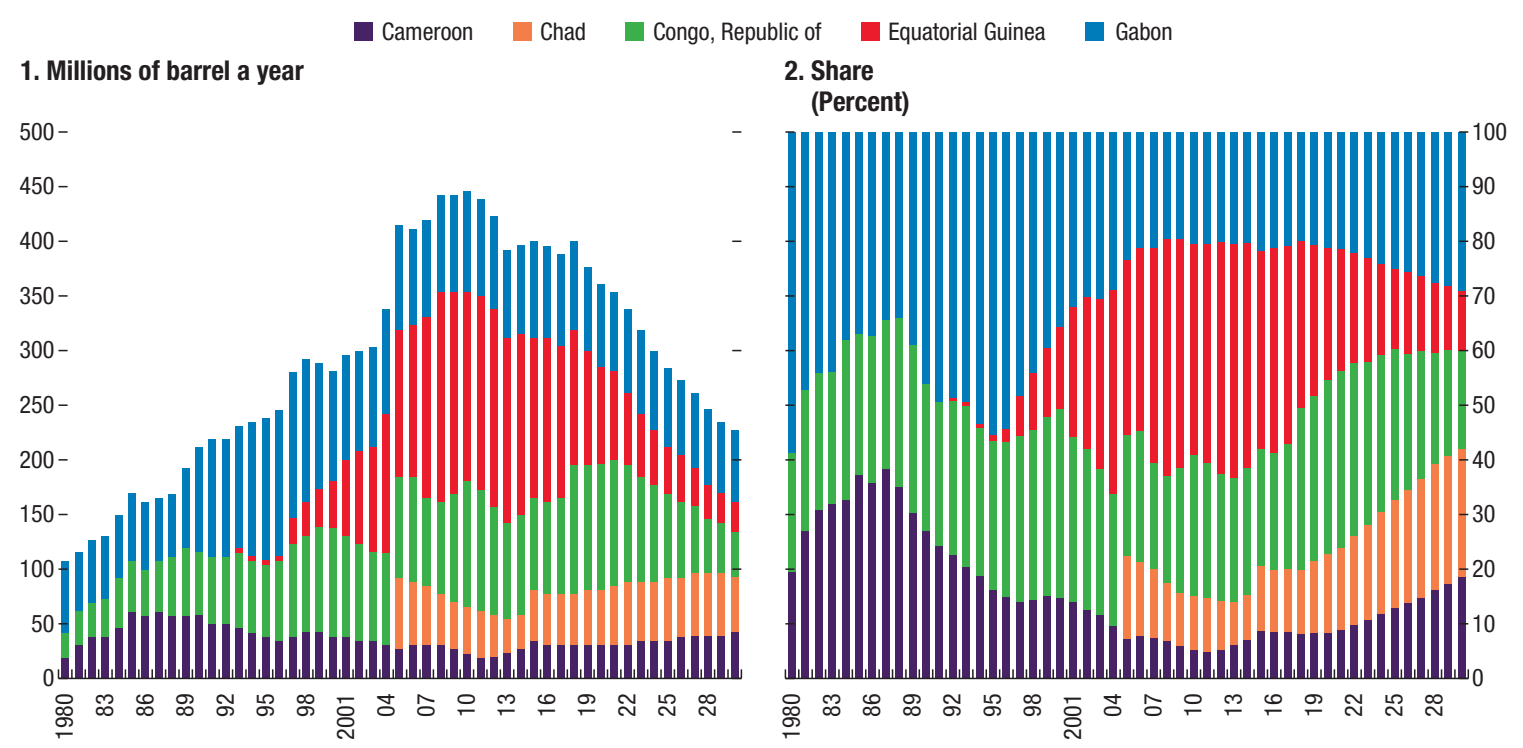

Sources: Country authorities; and IMF staff estimates and projections. Note: CEMAC = Central African Economic and Monetary Community.

since then Chad and the Republic of Congo have been classified as "in debt distress," and Gabon has experienced incidents of external payment arrears.

\section{CEMAC's Institutional Arrangements}

CEMAC is one of three currency unions worldwide with a common central bank under a fixed exchange rate regime. The other two are the West African Economic and Monetary Union (WAEMU), ${ }^{2}$ which also belongs to the CFA franc zone, and the Eastern Caribbean Currency Union (ECCU). ${ }^{3} \mathrm{~A}$ fourth currency union, the euro area, operates under a flexible exchange rate regime and issues a reserve currency. ${ }^{4}$ Discussions regarding the establishment of other currency unions in sub-Saharan Africa and elsewhere are ongoing, but they are at preliminary stages. ${ }^{5}$

\footnotetext{
2The WAEMU comprises Benin, Burkina Faso, Côte d'Ivoire, Guinea Bissau, Mali, Niger, Senegal, and Togo.

${ }^{3}$ The ECCU comprises Antigua and Barbuda, Dominica, Grenada, St. Kitts and Nevis, St. Lucia, and St. Vincent and the Grenadines, and two territories of the United Kingdom: Anguilla and Montserrat. The Eastern Caribbean dollar is pegged to the US dollar under a quasi-currency board arrangement at EC $\$ 2.70$ per US dollar. The Eastern Caribbean Central Bank must statutorily cover at least 60 percent of base money with its international reserves, although in practice the coverage has been much higher (van Beek and others 2000).

${ }^{4}$ Monetary policy in the euro area is the responsibility of the European Central Bank, which is governed by a Governing Council consisting of the heads of national central banks and an Executive Board.

${ }^{5}$ Among other regional groupings, the Economic Community of West African States, the East African Community, the Gulf Cooperation Council, and the Association of South-East Asian Nations include the adoption of a common currency as a medium-to-long-term goal.
} 
Table 2. CEMAC: Selected Partners' Trade Shares, 1995-2015 (Percent of Total Trade)

\begin{tabular}{lrrrrrrrr}
\hline & $\mathbf{1 9 9 5}$ & $\mathbf{2 0 0 5}$ & $\mathbf{2 0 1 0}$ & $\mathbf{2 0 1 1}$ & $\mathbf{2 0 1 2}$ & $\mathbf{2 0 1 3}$ & $\mathbf{2 0 1 4}$ & $\mathbf{2 0 1 5}$ \\
\hline European Union & 49.1 & 31.5 & 31.7 & 26.0 & 28.1 & 22.8 & 20.2 & 27.2 \\
United States & 21.0 & 26.9 & 24.9 & 25.8 & 17.0 & 13.3 & 9.5 \\
Developing Asia & 3.3 & 17.3 & 18.8 & 21.2 & 23.1 & 28.0 & 34.9 & 31.6 \\
China & 2.1 & 14.6 & 13.5 & 16.9 & 17.1 & 21.9 & 26.6 & 21.0 \\
India & 0.2 & 0.9 & 2.9 & 0.9 & 4.4 & 5.5 \\
\hline
\end{tabular}

Sources: IMF, Direction of Trade Statistics.

Note: CEMAC $=$ Central African Economic and Monetary Community

CEMAC was created by a monetary cooperation agreement between member states and France on November 22, 1972, entrusting the BEAC with the privilege of issuing a single currency (the CFA franc), ${ }^{6}$ defining a common monetary policy, and holding and managing the international reserves of member states. ${ }^{7}$ CEMAC operates under a fixed exchange rate regime, with full convertibility and unrestricted capital transfers within the CFA franc zone. The CFA franc is pegged to the euro and is freely convertible at the fixed exchange rate. However, the fixed parity is adjustable if required by economic conditions and following consultations between CEMAC authorities and the French government. ${ }^{8}$ There are generally no restrictions on current account transactions and payments. ${ }^{9}$ Capital flows within the CFA franc zone are also unrestricted, other than for administrative checks. Although capital outflows have tended to be small, transactions outside the CFA franc zone are nevertheless subject to prior approval by the BEAC to prevent large capital outflows. Convertibility operates through drawings on the BEAC's Operations Account (Compte d'opérations) at the French Treasury. ${ }^{10}$

The monetary agreement and related foreign exchange regulations also provide for the following:

\footnotetext{
${ }^{6} \mathrm{CFA}$ stands for Communauté Financière Africaine. The CFA franc (CFAF) is the common currency within CEMAC. The equivalent currency serves the same function within the WAEMU.

${ }^{7}$ Annex 1 discusses the role of international reserves in a currency union.

${ }^{8}$ The parity, in effect since the 1994 devaluation - the only parity change of the CFA franc since its creation-is CFAF 655.957 per euro. The institutional background is described in Gulde and Tsangarides (2008). Whether CEMAC needs pooled reserves in addition to France's guarantee is discussed in Annex 2.

${ }^{9}$ For instance, Gabon levies a tax on wire transfers, which gives rise to an exchange restriction (IMF 2017).

${ }^{10}$ Agbor considers the CFA franc zone a currency board, although he recognizes this "is a misnomer given that some of the key characteristics of a currency board, notably, full reserve coverage of base money, are not mandated" (Agbor 2012, 20). However, the convertibility guarantee offered by the French Treasury could be construed as making the CFA franc zone akin to a de facto currency board. Conversely, the IMF's Annual Report on Exchange Rate Arrangements and Exchange Restrictions characterizes the foreign exchange regime of the CFA franc as a traditional peg.
} 
- Repatriation and surrender of all foreign currency assets held by all CEMAC resident entities, including member states, to the BEAC. ${ }^{11}$

- Pooling of all CEMAC international reserves at the BEAC. ${ }^{12}$

- Obligation for the BEAC to maintain at least 50 percent of its international reserves on the Operations Account and for its international reserves to represent at least 20 percent of its sight liabilities. ${ }^{13}$

The credibility of the currency arrangement should be underpinned by a set of rules and safeguard measures:

- The foreign exchange regulation requires that all export proceeds be repatriated and surrendered to the BEAC within 30 days of collection.

- The multilateral surveillance mechanism imposes debt and budget rules to ensure coherence of member states' fiscal policies with the common monetary policy and the fixed exchange rate regime.

- The BEAC statutes include safeguard provisions designed to preserve monetary stability. First, a cap is put on accumulated direct financing from the BEAC to individual member states (this statutory ceiling is fixed at 20 percent of the previous year's ordinary fiscal revenue). ${ }^{14}$ Second, each member state is required to ensure that its position in the pool of foreign exchange reserves remains in credit. ${ }^{15}$ Third, emergency measures are automatically triggered when the foreign exchange cover ratio falls below 20 percent of the BEAC's sight liabilities for three consecutive months. Among others, these measures include an increase in the BEAC's interest rates and lower refinancing ceilings (which would be stricter in the countries with negative positions in the pool of reserves).

- The Operations Account Agreement enables the BEAC—in the event of reserves depletion-to "recall" all or part of the foreign exchange assets held by member states' public and private sectors, inside or outside the region, beginning with the countries that have debit positions in the pool of reserves (clause de ratissage or sweeping clause).

\footnotetext{
${ }^{11}$ In this paper, repatriation means bringing back (domiciling) foreign currency assets held abroad into the relevant state. Surrender means depositing repatriated foreign currency assets with the central bank (directly or through an authorized dealer) in exchange for domestic currency. Repatriation and surrender of export proceeds were not strictly enforced in the past.

${ }^{12}$ See Annex 3 for details and Annex 4 for a review of surrender requirements in other currency unions.

${ }^{13}$ Sight liabilities include notes and coins, sight deposits of banks, financial institutions and national treasuries, and foreign currency deposits (Williams and others 2001).

${ }^{14}$ The rule of the reference year was not systematically followed in some years. Advances above the cap were granted occasionally. In August 2017, the BEAC decided to consolidate outstanding statutory advances to governments into long-term loans and to cease granting them in the future.

${ }^{15}$ Although regional reserves have remained positive in the wake of the oil price shock, some member countries began to accumulate negative balances.
} 
This page intentionally left blank

CInternational Monetary Fund. Not for Redistribution 


\section{ChAPTER}

\section{CEMAC's International Reserve Adequacy}

\section{Developments in International Reserves}

The BEAC's gross international reserves increased 18-fold in 2001-13. They grew from US $\$ 1.1$ billion (5 percent of CEMAC GDP) in 2001 to US\$18.2 billion (19 percent of CEMAC GDP) in 2013 (Figure 2). ${ }^{1}$ This increase reflected the surge in CEMAC oil exports, mostly from the Republic of Congo and Equatorial Guinea, whose shares in the BEAC's total international reserves grew from 6.4 percent and 6.6 percent, respectively, in 2001 to 27.4 percent and 23.9 percent in 2013 . This growth stemmed mainly from the increase in oil prices, but also from rising oil production. Meanwhile, the imputed contributions of Cameroon and Central African Republic to the BEAC's international reserves fell from 30.8 percent and 11.0 percent, respectively, in 2001 to 18.0 percent and 1.0 percent in 2013. Between their peak in 2013 and end-2016, foreign exchange reserves held at the BEAC were on a downward trend.

Import coverage has mirrored developments in reserves. Community coverage rose from the equivalent of less than 1 month of prospective imports of goods and services in 2000 to almost 6 months by the end of 2012, while members' individual imputed reserve coverage ranged from $9 \frac{1}{2} 2$ months for the Republic of Congo to 21/4 months for Chad.

The oil-price slump has been tantamount to a major structural shock to CEMAC. Oil prices declined by some 52 percent between June 2014 and December 2016. With substantially lower foreign exchange earnings in the wake of the slump, official reserves declined to US\$4.2 billion at the end of 2016, equivalent to 1.9 months of prospective import coverage.

\footnotetext{
${ }^{1}$ Before the 1994 devaluation, the BEAC's international reserves stood at about CFAF 100 billion, approximately US\$160 million at the exchange rate of end-December 2016 (Avom 2012).
} 
Figure 2. CEMAC: Gross International Reserves, 2000-161

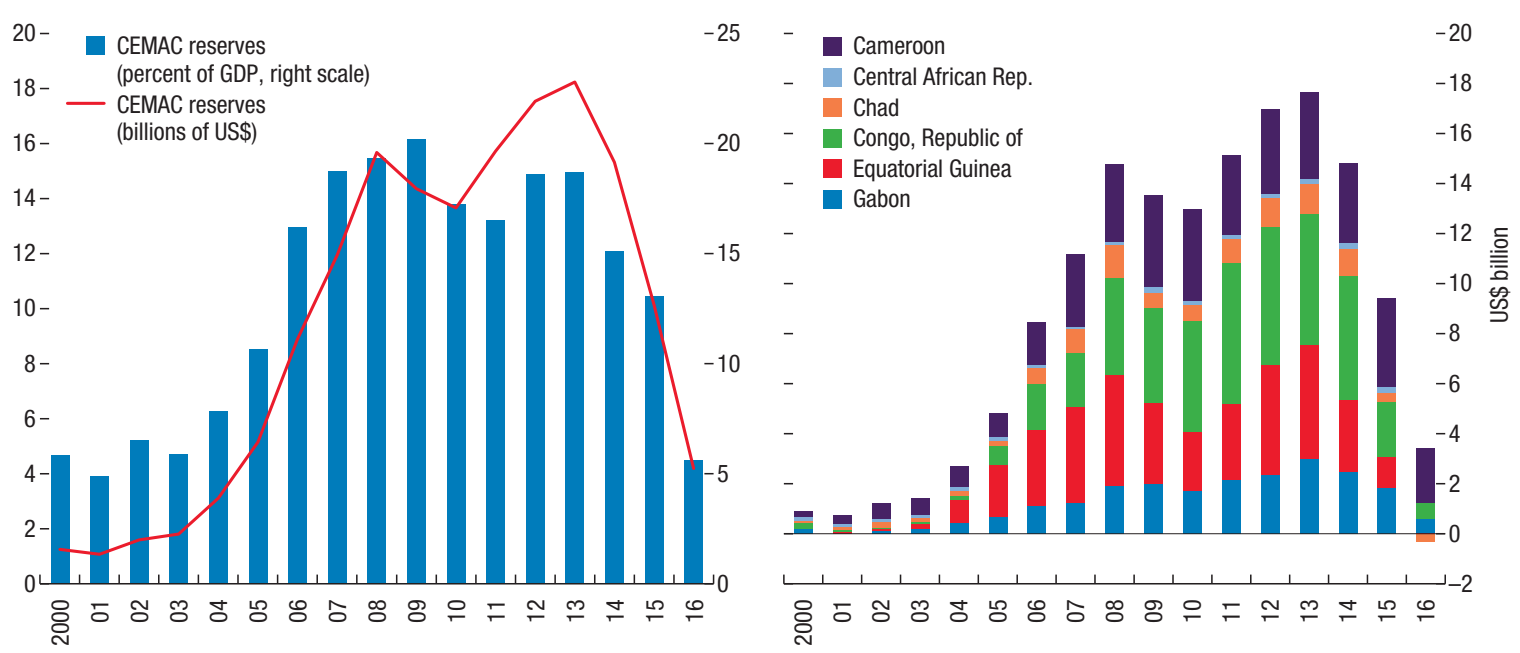

Sources: IMF, AFR database; IMF, International Financial Statistics; and IMF staff calculations.

Note: $\mathrm{CEMAC}=$ Central African Economic and Monetary Community.

${ }^{1}$ Total CEMAC reserves are higher than the sum of the reserves of individual countries because of the BEAC's own reserves

\section{Foreign Currency Assets Held Outside the BEAC}

In recent years, a share of CEMAC's foreign currency assets has been held overseas by some member states. Partial noncompliance with the reserve pooling requirement has persisted, particularly on the part of large oil exporters. Estimates based on indirect methods suggest that foreign currency assets held overseas may have represented the equivalent of up to 22 percent of the BEAC's international reserves at the end of 2016 (Figure 3), down from 36 percent at the end of $2009 .^{2}$

The reluctance of some member states to surrender all their foreign currency assets may be motivated by several considerations, including the following:

- The need to satisfy counterparty fund deposits requested by some development partners to guarantee financing.

- A desire to retain full ownership and control.

- A desire to earn higher returns than from deposits at the BEAC.

- Concerns about the BEAC's governance and the losses it incurred in the past.

- Concerns about a possible devaluation of the CFA franc.

- Concerns about the free-rider issue. ${ }^{3}$

\footnotetext{
${ }^{2}$ Indirectly derived from data from the Bank for International Settlements on overseas deposits by CEMAC's nonbanking sector.

${ }^{3}$ The free-rider issue arises when a member country does not contribute its agreed-upon share to the pool of common reserves. The issue is discussed later in this paper.
} 


\section{Figure 3. CEMAC: Member States' Reserves by Domicile, 2007-16 \\ (Billions of US dollars)}

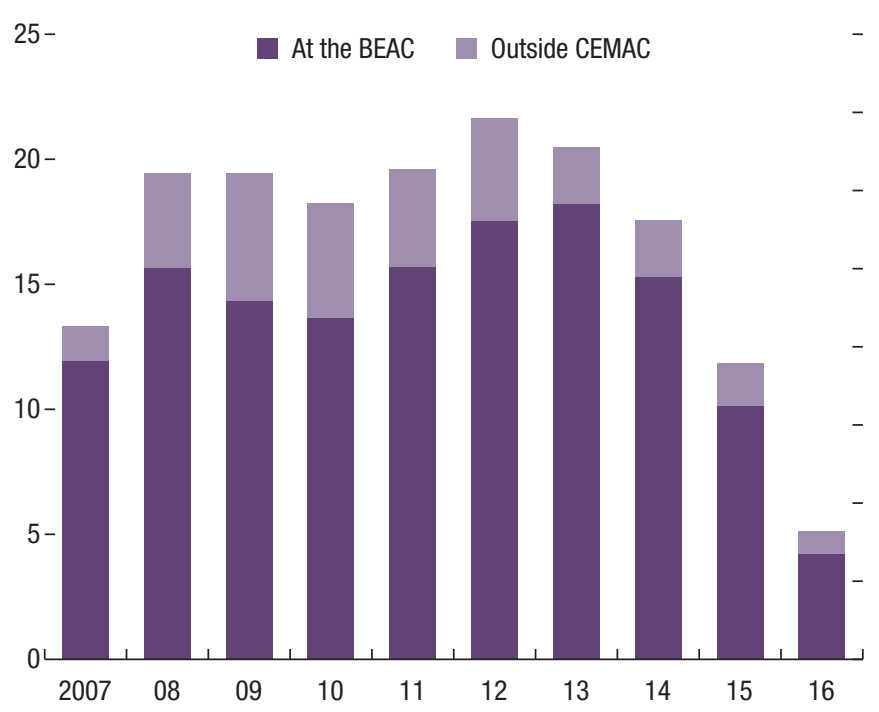

Sources: IMF, AFR database; and IMF staff calculations.

Note: BEAC = Central Bank of Central African States; CEMAC = Central African

Economic and Monetary Community.

From a more operational standpoint, it appears that possible suboptimal management of foreign currency operations by the BEAC could also be a reason for incomplete repatriation. Some member states maintain foreign currency accounts with foreign banks to ensure the smooth management of their foreign exchange operations. Such arrangements violate the convention governing CEMAC. The BEAC is currently studying the possibility of opening foreign currency accounts with foreign central and commercial banks to facilitate foreign exchange operations. Such a decision, once made, could enhance the BEAC's role as a foreign currency custodian for the member states, speed the execution of foreign currency transactions, and potentially lower transaction costs. Ultimately such a development could encourage full repatriation of member states' foreign assets.

\section{CEMAC's Reserve Adequacy Assessment}

After a bottoming out of international reserves, projections point to a moderate recovery in the medium term. As noted earlier, the BEAC's international reserves declined to US\$4.2 billion at the end of 2016 (excluding non-repatriated assets), equivalent to 1.9 months of prospective imports 
(Figure 4). Even if all overseas foreign currency assets were surrendered, reserves would rise only modestly. World Economic Outlook projections are for a modest price recovery to US $\$ 52$ per barrel in 2021, with continued high volatility, well below the level of US $\$ 132$ a barrel in July $2008 .{ }^{4}$ In addition, CEMAC's oil production is projected to decline from 941,000 barrels a day in 2015 to 901,000 barrels in 2021. Based on these projections, and including projected financial support from international financial institutions, CEMAC's reserves would recover to US $\$ 10.5$ billion (4.4 months of prospective imports) at the end of 2021 . However, if oil prices were to resume a declining trend, the ensuing contraction in oil export proceeds could jeopardize CEMAC's external stability.

Identifying an appropriate reserve adequacy benchmark for CEMAC is not a straightforward task given the Community's unique features. CEMAC economies are sensitive to terms-of-trade shocks from international commodity price fluctuations. In addition, they are relatively undiversified, depending primarily on oil, and have limited access to international financial markets. The pegged exchange rate of the common currency increases the complexity of the assessment. Against this backdrop, and in view of the large amount of imports related to infrastructure investment, the ratio of reserves to imports is of particular relevance and should be the primary reserve adequacy indicator. The ratio of reserves to short-term debt is also relevant, insofar as it captures solvency and liquidity risks rather than rollover risks. ${ }^{5}$ Similarly, the ratio of reserves to base money could be used to benchmark the BEAC against traditional currency boards, given that it is also similar to the required coverage ratio prescribed in the agreements with France (Annexes 5 and 6).

At 1.9 months of import coverage, the BEAC's reserves at the end of 2016 were below recommended levels. These levels are generally higher for fixed exchange rate regimes, commodity exporters, and fragile states than for other low-income countries, reflecting their greater vulnerability to exogenous shocks. Baker and Nxumalo (2012) estimate, based on a panel regression of 71 low-income countries, that required reserve levels should be about six months of imports of goods and services. Deléchat and Martijn (2008) find this level of reserves would cover a two-standard-deviation current account shock for CEMAC countries. Nonetheless, they conclude that reserves coverage of four months should suffice for the CEMAC, taking into consideration the benefits of pooled reserves. ${ }^{6}$

${ }^{4}$ Oil price projections in this paper are based on the projections in the IMF's World Economic Outlook reports of October 2017.

${ }^{5}$ The predominance of official medium- and long-term external debt, rather than short-term external debt, means that rollover risk is relatively limited for CEMAC.

${ }^{6}$ However, the volatility of oil prices and issues regarding data reliability could require an extra margin of safety. 


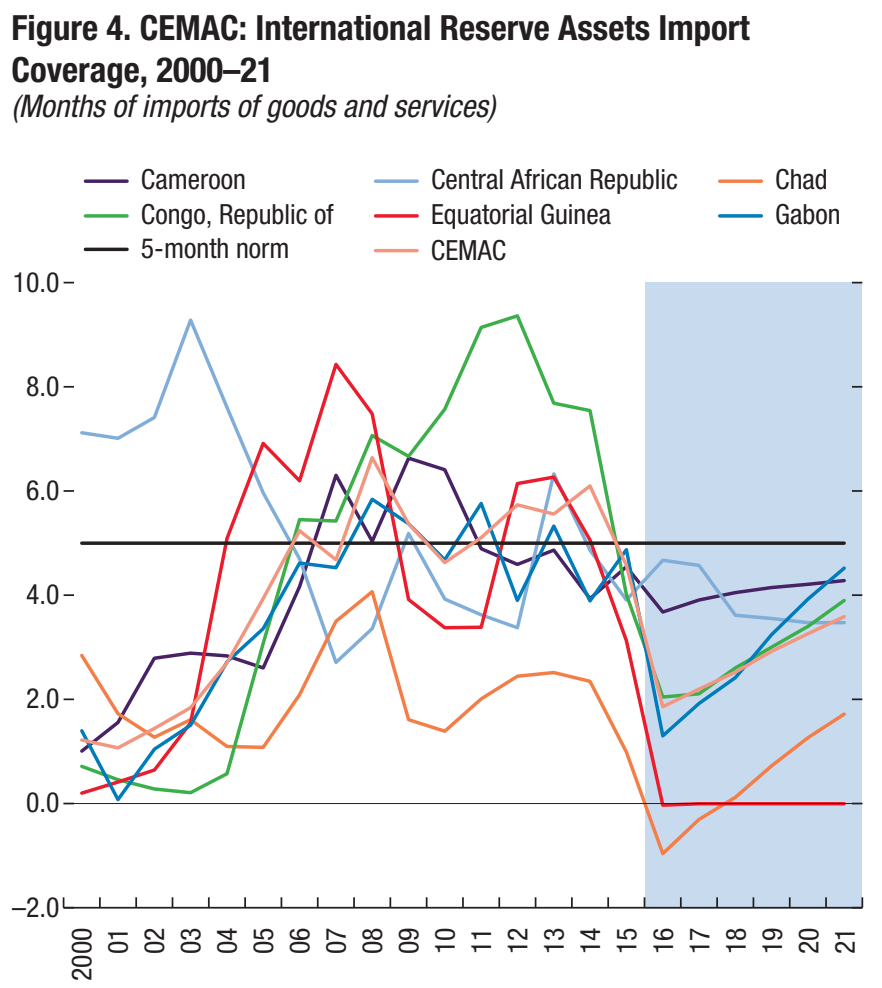

Sources: World Economic Outlook database; and IMF staff estimates and projections.

Note: $\mathrm{CEMAC}=$ Central African Economic and Monetary Community.

The adequacy of the BEAC's reserves at the end of 2016 was mixed when compared with common debt and monetary metrics. ${ }^{7}$ At the end of 2016, the regional reserve pool was equivalent to more than 171 percent of the short-term debt falling due in 2016, it represented 23 percent of broad money, and it covered 114 percent of base money, thus exceeding the coverage that would be required for a currency board (Table 3). However, when using the composite reserve adequacy index developed by IMF staff (IMF 2011 a; 2013), the BEAC's reserve adequacy matrix ratio of 98 percent at the end of 2016 was below the level considered adequate, which would be between 100 percent and 150 percent.

Model-based estimates of reserve coverage also indicate that the level at the end of 2016 was well below the recommended range. An approach based on Dabla-Norris, Kim, and Shirono (2011) yields a recommended coverage of between 5 and 12 months of imports in 2016, depending on the interest rate differential with the rest of the world (Figure 5). With an estimated average

\footnotetext{
${ }^{7}$ Reserve metrics, although widely used, do not necessarily provide an appropriate benchmark for reserve adequacy — they simply show where a country/union stands compared to peers.
} 
Table 3. CEMAC: Reserve Adequacy Indicators, 2011-16

\begin{tabular}{|c|c|c|c|c|c|c|}
\hline & 2011 & 2012 & 2013 & 2014 & 2015 & 2016 \\
\hline Reserves (US\$ billion) & 15.7 & 17.5 & 18.2 & 15.3 & 10.1 & 4.2 \\
\hline Months of imports & 5.1 & 5.7 & 5.4 & 5.7 & 4.4 & 1.9 \\
\hline Percent of short-term debt & 1,786 & 1,680 & 854 & 741 & 653 & 171.9 \\
\hline Percent of broad money & 85.6 & 88.7 & 83.6 & 65.9 & 53.1 & 23.1 \\
\hline IMF reserve adequacy matrix (US\$ billion) & 6.5 & 6.4 & 6.8 & 7.3 & 4.8 & 4.3 \\
\hline Percent of reserve adequacy indicator & 242.3 & 272.1 & 269.2 & 210.6 & 211.5 & 98.1 \\
\hline
\end{tabular}

Souces: BEAC; and IMF staff estimates.

Note: BEAC $=$ Central Bank of Central African States; CEMAC = Central African Economic and Monetary Community

opportunity cost of holding reserves of 4.6 percent for CEMAC, reserve coverage should be between 6.3 months and 7.8 months of imports. ${ }^{8}$

Against this backdrop, international reserves at the BEAC covering five months of imports could be considered a desirable objective, or target. ${ }^{9}$ This recommendation is consistent with the assessment made by IMF staff in the context of the 2014 regional consultation with CEMAC. ${ }^{10}$ A five-month threshold was also considered appropriate by the aforementioned ad hoc working group in a technical note prepared in August 2012. The working group assessed reserve adequacy based on the need to cover five months of CEMAC imports and the following year's external public debt service. ${ }^{11} \mathrm{In}$ 2015, the BEAC deemed that an intermediate risk coverage should consist of five months of imports of goods and services and 100 percent of public external debt service. Thus, the emerging consensus seems to be for a recommended level of reserves equivalent to five months of imports. ${ }^{12}$

To strengthen the commitment to adequate international reserves, CEMAC's Committee of Finance Ministers should adopt five months of imports as the BEAC's reserve target. This would also put in perspective the relevance of the 20 percent external coverage of the money supply established by the BEAC's

${ }^{8}$ This approach does not take into account CEMAC members' overseas reserves.

${ }^{9}$ Prospective imports would be a better indicator from an economic point of view, as they are forward looking. However, they are not well fitted to be used as a legal target, because they are not a statistical quantity, but a forecast. Consideration should be given to how to make prospective imports a possible legal target.

${ }^{10}$ However, an analysis of international reserve targets for natural resource exporters in sub-Saharan Africa, conducted in the context of the April 2012 issue of the IMF's Regional Economic Outlook for Sub-Saharan Africa, estimated that a level of international reserves for CEMAC, covering five months of imports of goods and services, would be somewhat less than adequate. These results were based on the methodology developed by IMF staff (IMF 2011a) and Dabla-Norris, Kim, and Shirono (2011).

${ }^{11}$ Coverage of five months of imports corresponds to an intermediate benchmark among three considered by the working group. This benchmark takes into account the strong volatility of foreign currency assets in CEMAC. However, the choice of the threshold of five months of imports and 100 percent of external debt service implies an excess of benchmarks, because what matters should be which one of the two criteria is stricter (Comité Mixte sur le Rapatriement des Avoirs en Devises des États Membres de la CEMAC, 2012b).

${ }^{12}$ Consideration could be given to track some concept of net reserves, which excludes IMF borrowing and other short-term borrowing to build more stable and sustainable reserves. 
Figure 5. CEMAC: Model-Based Recommended Optimal

Reserves, 2016

(Months of next year imports)

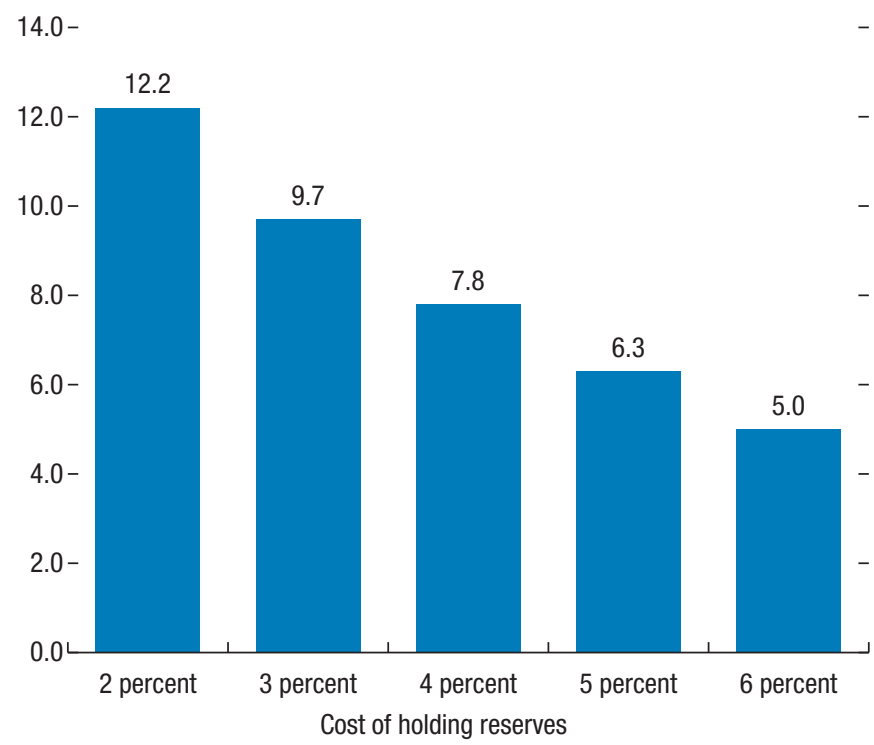

Sources: IMF staff calculations, based on Dabla-Norris, Kim, and Shirono (2011). Note: $C E M A C=$ Central African Economic and Monetary Community.

charter (the ratio of average foreign assets to average sight liabilities) as a measure of the minimum level of international reserves. This ratio may well be a contractual benchmark within the monetary cooperation agreement with France, but it may not be sufficient for preserving the peg of the CFA franc to the euro in all circumstances.

At the end of 2016, the BEAC's reserves did not meet the recommended target of five months of imports. Following strong economic reforms to rebuild the level of foreign reserves, and with financial support from the IMF, a reversal of the recent drop in foreign reserves is expected. However, the latest projections do not anticipate a return to the five-month target in the medium term. Even with the possible repatriation of foreign currency assets currently held abroad, reserves would fall short of the target. On this basis, it seems appropriate to focus on how to ensure that the target is sustainably met in the medium term. 
This page intentionally left blank

CInternational Monetary Fund. Not for Redistribution 


\section{ChAPTER}

\section{International Reserves and Fiscal Rules}

The previous analysis on required (that is, targeted) reserves is related to fiscal stabilization. Possible excess reserves can then be linked to longer-term intergenerational equity.

\section{Fiscal Buffers in CEMAC}

During the 2000s, CEMAC generated large consolidated fiscal surpluses. CEMAC's consolidated annual fiscal surplus averaged 2.5 percent of regional GDP in 2000-13, mainly on behalf of the Republic of Congo and Gabon. This allowed both an increase in government savings, including in the form of government deposits with the BEAC, and a reduction in public debt ratios. As noted above, the BEAC's international reserves rose sharply during this period, but then have declined (Figure 6).

In recent years, fiscal stances have varied across member countries. With higher oil prices, most countries improved their fiscal positions in 2005-09. Since then, however, most member countries have launched ambitious infrastructure programs whose cost, compounded by the contraction of fiscal revenues in the wake of the oil-price slump, has resulted in a significant erosion of fiscal buffers (Figure 7).

Since 2012, oil prices have fallen short of what is needed to balance the budgets of CEMAC's largest oil producers. Figure 8 depicts the evolution of the average price per barrel of oil (the equilibrium price) required to balance the aggregated budget of the four largest CEMAC oil exporters (Chad, Republic of Congo, Equatorial Guinea, Gabon). ${ }^{1}$ The equilibrium price rose from

\footnotetext{
${ }^{1}$ Cameroon is not included because the relatively small share of its oil revenue in total fiscal revenue would yield an unrealistically high equilibrium price.
} 

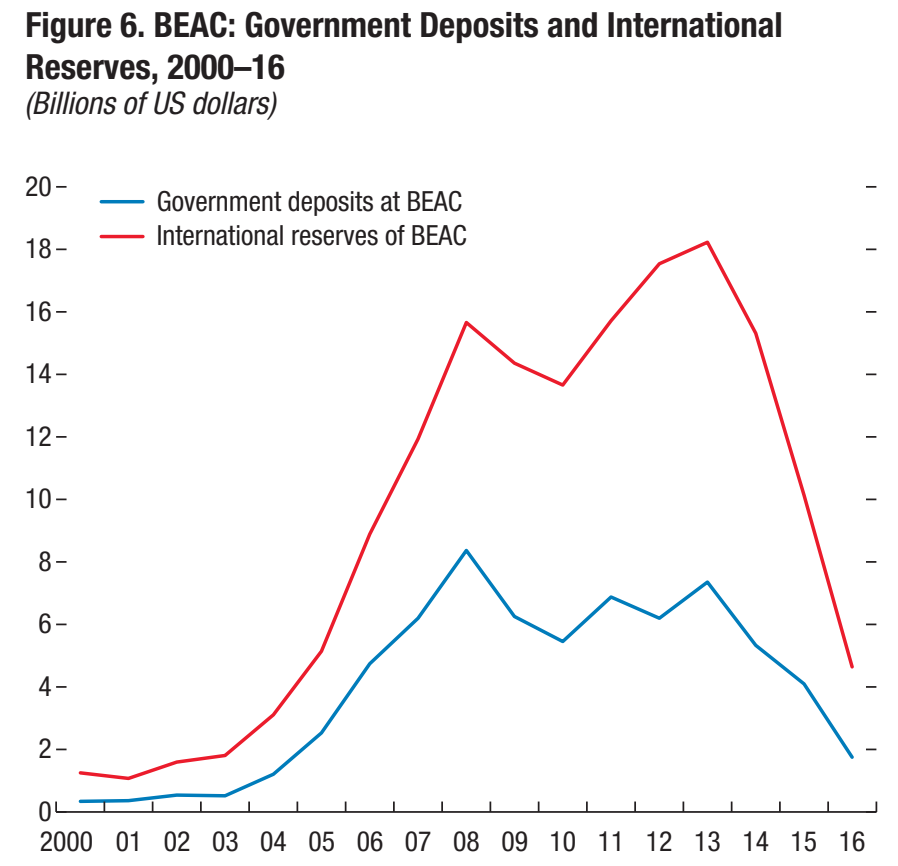

Sources: IMF, International Financial Statistics; and IMF staff estimates Note: $\mathrm{BEAC}=$ Central Bank of Central African States; CEMAC $=$ Central African Economic and Monetary Community.

US\$52 per barrel in 2008 to US\$123 per barrel in 2013, reflecting a weakening regional fiscal stance, before declining to US\$93 per barrel in 2016 as a result of limited fiscal consolidation in the wake of the oil-price shock.

\section{Fiscal Anchoring of Reserves}

CEMAC countries are subject to fiscal convergence criteria as part of the regional surveillance framework. Since January 2017, a first criterion proscribes the adjusted fiscal deficit from falling below -1.5 percent of GDP, and a second criterion requires the stock of total public debt (domestic and external) to be less than 70 percent of GDP. ${ }^{2}$ In addition, a supplementary criterion applies to the non-oil primary balance. ${ }^{3}$ Although these indicators have

\footnotetext{
${ }^{2}$ The new fiscal rule requires that the difference between the overall fiscal balance and a new commodity (that is, oil) savings rule must be equal to or higher than -1.5 percent of GDP. The savings rule is defined as 20 percent of oil revenues of the current year adjusted by the average change in oil revenues during the past three years, with a coefficient of 80 percent. For details, see Directive N.02/16-UEAC-093-CM-30, dated February 3, 2016. See also IMF (2013b, 2014b).

${ }^{3}$ The non-oil primary balance is the difference between non-oil revenue and total expenditure excluding interest payments on external and domestic debt.
} 
Figure 7. CEMAC: Fiscal Stances, 2000-16
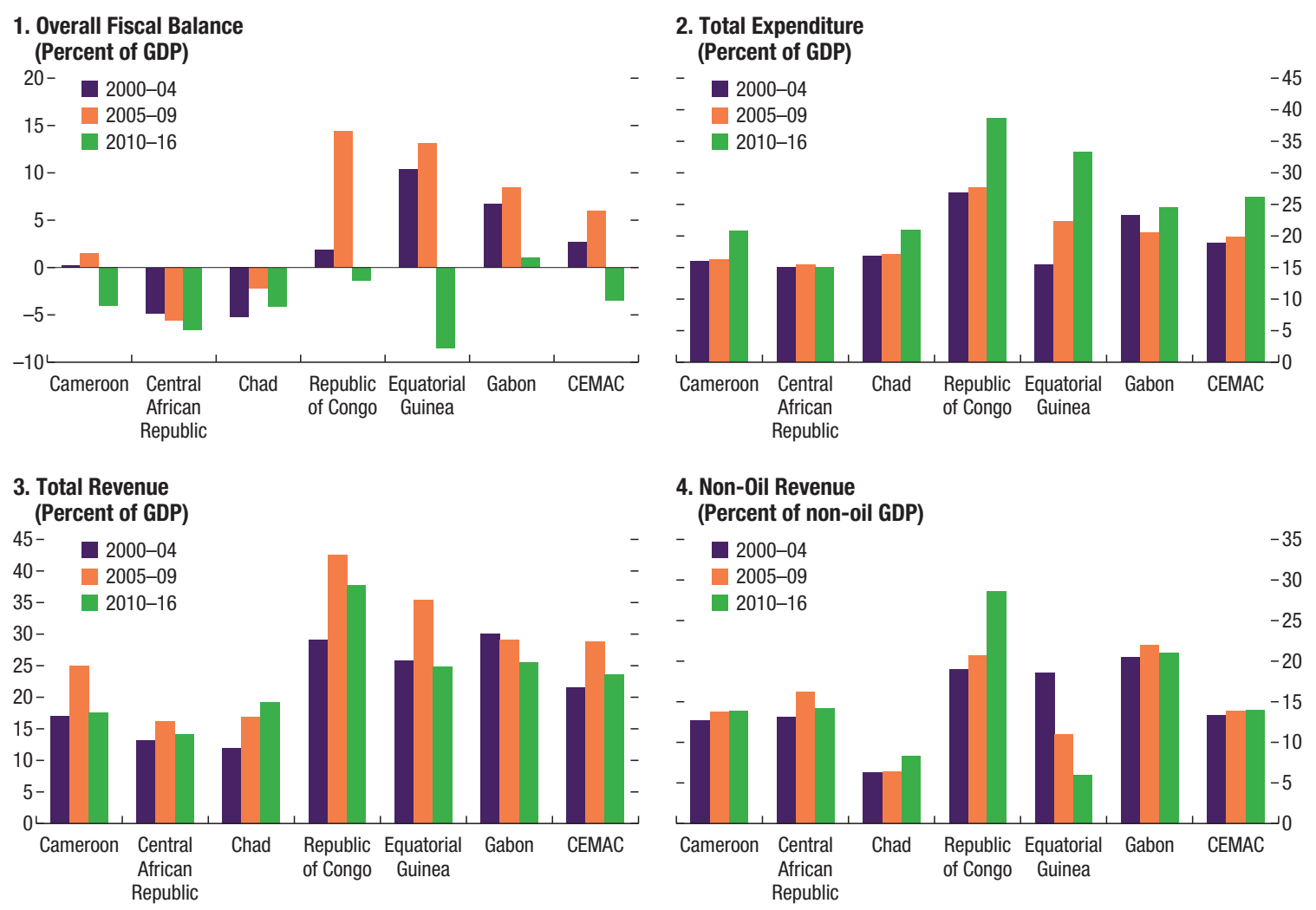

Sources: IMF, AFR database; and IMF staff estimates.

Note: $C E M A C=$ Central African Economic and Monetary Community.

limitations, the new fiscal balance rule provides a better anchor for assessing the fiscal stance than the previous one based on the basic fiscal balance. ${ }^{4}$

The importance of building adequate reserves implies that appropriate fiscal rules must be put in place. Annex 7 discusses possible fiscal rules for CEMAC. The rationale for fiscal rules is to ensure fiscal stability and debt sustainability, considering resource exhaustibility, revenue volatility, consumption smoothing, scaling up of public investment, and intergenerational equity. Accordingly, fiscal stances need to be adjusted in member countries to ensure fiscal buffers are built to support the peg, and eventually, to build long-term wealth.

\footnotetext{
${ }^{4} T$ The basic fiscal balance is defined as the overall fiscal balance excluding grants and foreign-financed investment.
} 
Figure 8. CEMAC: Average Equilibrium Price per Barrel of Oil, 2008-16

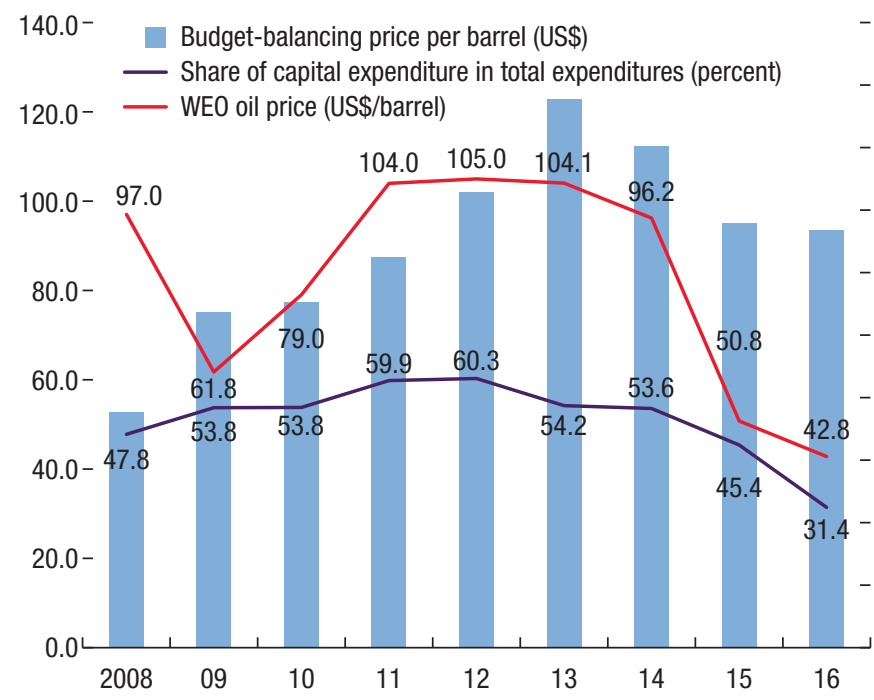

Sources: World Economic Outlook (WE0); and IMF staff estimates.

Note: CEMAC = Central African Economic and Monetary Community.

${ }^{1}$ Excluding Cameroon and Central African Republic. 
Chapter

\section{Recommendations for a New Reserve Management Framework}

\section{Vulnerability of the Status Quo}

Member states' current reserve pooling practices are a potential source of macroeconomic instability. As noted earlier, several member states are not complying with the full surrender requirement. This practice was barely sustainable with the price of oil above US $\$ 100$ a barrel and a consolidated CEMAC budget close to balance, but it has turned into a major risk since the oil-price slump. The BEAC's reserves are not deemed adequate under current projections, with limited fiscal buffers remaining. They fall short of what would be needed to defend the peg credibly under adverse developments. The oil-price shock underscores the critical need for CEMAC member countries to comply fully with the reserve pooling requirement.

Lack of action and fiscal policy drift entail risks and may prove costly. Although member states may be willing to act in a concerted manner in the event of a crisis by providing additional foreign currency assets to the BEAC as necessary, there is no certainty that such an ad hoc approach would result in a mutually acceptable solution in a sufficiently timely manner. While recognizing that the sweeping clause is in place to allow the BEAC to mobilize additional reserves in such an eventuality, this procedure has never been tested and it remains unclear whether the BEAC can enforce it.

\section{Sovereign Asset Management in Resource-Rich Countries}

Resource-rich countries, which can accumulate excess reserves beyond precautionary targets, need to articulate their short-term savings versus long-term investment strategies (see IMF 2014b). When countries accumulate reserves in excess of those needed for monetary and exchange rate policy purposes, an investment strategy that boosts returns on foreign assets while maintaining 
a prudent risk profile may be appropriate. This approach is common with various types of stabilization funds used as investment vehicles. At the same time, investment strategies should be supported by an appropriate governance structure. This safeguard is essential to defining risk tolerance and to having proper monitoring and reporting of risks and returns. An adequate institutional framework for the governance structure should also be in place to ensure consistent implementation of investment strategies over time. In designing the investment framework, some basic issues need to be addressed, including (1) an assessment of required versus excess reserves, (2) an articulated risk tolerance and investment strategy, and (3) an appropriate institutional arrangement to support implementation of the investment strategy. A critical issue is the design of a mechanism to ensure the timely replenishment of required reserves from excess reserves held in investment funds, when necessary.

\section{A New CEMAC Savings Framework}

\section{Principles for a New CEMAC Savings Framework}

A successful regional fiscal savings framework requires strong fiscal coordination and effective implementation of the regional convergence framework. Fiscal policies in many CEMAC countries have typically been procyclical because the region enjoyed high oil revenue, and debt relief created fiscal space for infrastructure financing (see Mpatswe, Tapsoba, and York 2012). However, since mid-2014 the fiscal situation has deteriorated, warranting strengthened fiscal coordination consistent with CEMAC's external stability.

A new savings framework must meet several Community-wide principles:

- Solidarity: The common external stability objective is supported by member countries for the benefit of the Community, implying that CEMAC members agree to act in concert and to support one another in this common endeavor.

- Sovereignty: Decisions on the extraction and sale of natural resources are the competence of member states. The management of export receipts should not be encumbered by CEMAC rules beyond those necessary for implementing CEMAC-wide reserve rules.

- Fairness: Efforts requested from member states should be proportional to their abilities. Findings of noncompliance with CEMAC rules by member countries should be made based on objective criteria. Remedial actions should be discussed and agreed to by peers.

- Simplicity: Regional rules of savings management should be straightforward, transparent, and easy to enforce. 
- Clarity of purpose: Only one policy objective should be assigned to each savings instrument.

- Rule of law: Member states are expected to comply with all regional savings rules, commit best efforts, and where appropriate, take measures to restore compliance in a timely manner. These expectations need to be supported by robust checks and balances in addition to possible sanctions for persistent noncompliance.

- Transparency: The extraction of natural resources and the accumulation of related proceeds must be recorded and accounted for comprehensively and transparently and promptly shared with the BEAC and other member states. ${ }^{1}$

- Pragmatism: Reform of the regional savings framework is a major undertaking. A new framework will require regular reassessment as it is implemented. A pragmatic process to adapt to new circumstances and rules is critically important.

The framework should reflect fairly each member state's contribution to the pooled reserves. It should be based on two principles: (1) the need for each member state to contribute its fair share to the regional reserve pool, and (2) the requirement for other member states to step in if a member fails to meet its required contribution (principle of solidarity). If a member cannot contribute fully to pooled reserves, appropriate mechanisms should be developed to recognize the liability of this member state. This liability should be reflected in the BEAC's balance sheet as debt owed to the central bank.

\section{Structure for a New CEMAC Savings Framework}

A common pool of reserves alone may not be sufficient to address member states' varying self-insurance needs, risk exposures, and development programs. These constraints are best overcome through a framework distinguishing the management of pooled international reserves from that of excess reserves. The proposed framework thus comprises two tiers that are characterized by (1) clear macroeconomic policy purposes, (2) consistent governance arrangements, and (3) associated investment rules. ${ }^{2}$ The first tier comprises a common pool of international reserves, dedicated to defending the peg and regional monetary policy objectives. The second tier manages excess reserves using national stabilization funds (NSFs) established to mitigate country-specific shocks — thus also safeguarding each country's ability to contribute to the Community pool and ultimately defending the peg. The

\footnotetext{
'This is consistent with several member countries' membership in the Extractive Industries Transparency Initiative.

${ }^{2}$ The proposed framework may require modification to parts of the CEMAC Treaty and to the monetary cooperation agreement with France.
} 
new framework would still require full surrender of foreign assets, but would allow member states' unimpeded use of funds deposited in NSFs. ${ }^{3}$

\section{Tier I-Pooled international reserves}

The unencumbered common pool of reserves under the first tier recognizes the prominent role of the common currency and its fixed exchange rate with the euro. The way in which the first tier is mobilized, with country-specific commitments scaled to the needs of each member, would strike a reasonable balance between mutual commitment of member states (application of the principle of solidarity) and the pursuit of a common monetary policy (which embodies the principle of stability).

Under the first tier, each member state would surrender its export proceeds to the BEAC until it has provided enough to cover five months of its imports on a continuous basis. This provides the BEAC with a five-month import coverage for the Community as a whole. The characteristics of the first tier would be essentially the same as those for pooled reserves under the existing arrangements:

- Purpose: Reserves are pooled to support the common peg and external stability.

- Ownership: The BEAC is the owner of the pooled international reserves.

- Management: The pooled reserves are invested by the BEAC according to current practices, with one-half deposited in the Operations Account at the French Treasury and the other half managed with the objectives of preserving capital and maintaining appropriate liquidity while minimizing risks.

\section{Tier II-National stabilization funds}

Member states would retain direct control of foreign assets in excess of their target reserves; these assets would be placed in their NSFs at the BEAC. ${ }^{4}$ These funds could reflect the varying liquidity needs, investment horizons, return objectives, and risk profiles of member countries. This approach also recognizes the different wealth endowments of member states (application of the principle of fairness).

\footnotetext{
${ }^{3}$ The new framework builds on the existing framework ("Tier I") and proposes to add a new component ("Tier II").

${ }^{4}$ Creating NSFs may be a medium-term objective for CEMAC members, once oil prices recover and fiscal stances become sustainable. A cost-effective alternative to NSFs could be establishing a CEMAC-wide stabilization fund with country-specific, ring-fenced sub-funds. This approach would save on management costs and bypass management capacity constraints at the country level. The use of the BEAC for operational management of a regional stabilization fund could be considered because of BEAC's experience in managing official reserves and its existing systems for internal and external audit, reporting, and risk management.
} 
The operational characteristics of the NSFs would be as follows:

- Purpose: NSFs serve the dual purpose of providing (1) a safety buffer in case of a country-specific shock, and (2) additional insurance against Community-wide tail risks. The size of each fund would be tailored to reflect the degree of country-specific risk (for example, oil dependence) and thus would provide country-specific self-insurance. The amount of funds in the NSFs would be monitored under the regional surveillance framework. Contributions to NSFs come from excess export proceeds in boom years. Disbursements from NSFs in leaner years would be guided by an agreed-upon rule. The rules adopted for NFS operations need to be consistent with that member's fiscal rule, itself consistent with CEMAC's fiscal and external convergence framework and stability. ${ }^{5}$

- Ownership: NSFs belong to their respective countries.

- Management: NSFs are managed by the BEAC for ease of cross-country monitoring and economies of scale, but the BEAC acts strictly as fiduciary agent, without any claim to ownership. ${ }^{6}$ Accordingly, governance arrangements should distinguish between two roles for the BEAC: that of investment manager and that of fiduciary agent. To avoid conflicts of interest and political pressure, NSFs may not be invested in assets located in, or issued by, agents of CEMAC. NSF investment strategies (asset class, time horizon) would be similar to those for international reserves, but would be designed with guidance from the respective member state, with a possible higher level of risk for a higher level of return.

\section{Enforcement}

Enforcement should be based on a finding of noncompliance with the surrender requirement using objective indicators that can be continuously and easily monitored. A list of indicators and corresponding sources is to be drawn up. BEAC management should have an ex officio right to initiate a noncompliance procedure. For legitimacy, a finding of noncompliance should be the result of a decision by a majority of member states (according to modalities to be determined).

Remedial action should be proportionate to the extent of the impact of the noncompliance event and the extent to which it was beyond a member state's control. If an episode of noncompliance does not affect the broader stability

\footnotetext{
${ }^{5}$ The question of whether NSFs should be maintained in domestic or foreign currency is not discussed here, but foreign-currency-denominated NSFs could be attractive to some member states.

${ }^{6} \mathrm{An}$ exception to this rule, like the existing sweeping clause, would apply in the event of an emergency when the BEAC would be authorized on a temporary basis to use such funds for reserve or monetary management needs.
} 
of the Community and is largely involuntary (for example, a major shock or an economic downturn, largely beyond the short-term control of the authorities), the remedial action should be limited accordingly. If, however, the noncompliance jeopardizes the Community's external stability and is, at least to some extent, a matter of policy discretion (for example, reckless spending), then more restrictive measures could be envisaged, such as the application of the sweeping clause to the noncompliant country's NSF.

The proposed framework requires adequate statistics. A timely, appropriate, and standardized reporting system of exports, imports, and foreign assets is essential for robust implementation of the framework.

\section{Addressing the Free-Rider Issue}

A member country may be free riding if it is benefiting from the advantages of the Community while not contributing proportionately to its costs. Ideally, each member contributes its fair share to common reserves. ${ }^{7}$ But what happens if a country falls below its target? ${ }^{8}$ The answer to this question depends on the source of free riding, which can be of a temporary or a protracted nature, and may be voluntary (that is, unsustainable fiscal policy) or involuntary (external shock). In any event, the issue needs to be addressed to avoid abuse of the solidarity principle.

The solution to free riding requires binding rules on burden sharing. When the external position of a member country becomes unsustainable, measures need to be taken to bring the troubled country back in compliance with the common contribution norm. To mitigate the free-rider hazard, the solidarity principle could be invoked only during a limited time (a specified grace period) and for limited amounts (say, for up to $N$ months' worth of imports). The grace period is necessary for the defaulting member to be able to mobilize the financial means necessary to settle its outstanding obligations in an orderly manner (for instance, through liquidation of parts of its NSF). If a member's default exceeds the grace period or the authorized import-months equivalent $(N)$, the defaulting member should be required to take corrective measures to ensure restoration of its fair contribution to common reserves. To

\footnotetext{
${ }^{7}$ Each country contributing the equivalent of five months of its imports would, ipso facto, ensure reaching the five-month target for the union. However, other, country-specific targets could be considered, provided the five-month target for the union is preserved.

${ }^{8}$ With common exchange rate and monetary policies, fiscal and structural policies are the key instruments at the national level for cushioning shocks and promoting economic activity. National authorities may be motivated to engage in opportunistic behavior in this context, given that the cost of an expansionary fiscal policy, such as loss of competitiveness and reduction in international reserves, is shared by the whole Community. This is especially true for smaller member countries because the impact of their unsustainable policies on the common good of the Community is relatively small.
} 
guarantee that the adjustment policies envisioned are appropriate, the rules could require that the policies be carried out under a peer-reviewed, multilateral surveillance process. Elements of time-bound gradualism could be built into this framework to allow the various mechanisms to operate smoothly and the defaulting member to adapt to its constraints.

A mechanism should be specified for replenishing the BEAC's international reserves if they fall below the required level. The financial stability of CEMAC requires that it always have adequate international reserves, meaning that the BEAC is able to call on other members to step in for the defaulting member (principle of solidarity). Agreement among the member states and the BEAC is necessary regarding the process by which the required level of international reserves would be restored in such cases. In particular, a mechanism enabling the BEAC to recall part or all of the liquid assets held in member states' NSFs, if warranted, would need to be devised to bring the required reserves back to their targeted level. ${ }^{9}$ Some degree of gradualism should be accepted to reduce the risk of substantial capital losses from unplanned, abrupt withdrawals.

\footnotetext{
${ }^{9}$ Repayments to members that step in under the solidarity principle could be supplemented by interest payments on the amounts advanced by them.
} 
This page intentionally left blank

CInternational Monetary Fund. Not for Redistribution 


\section{Chapter}

\section{Considerations for Reserve Management}

Stable resources are required to support an adequate level of pooled international reserves. Reserve stability can only be achieved if the BEAC's equity and stable liabilities are equivalent to the target level of international reserves. In the BEAC's balance sheet, equity (fonds propres/fonds de dotation, résultat, réserves), currency in circulation (billets et pièces en circulation), and special drawing right allocations may be considered stable resources for this purpose. To some extent, required reserves could also be considered stable resources, provided the level of deposits in the region is stable. Because this has not been the case recently, as illustrated by the simplified balance sheet in Table 4 (see the decline in required reserves between 2015 and 2016), it might be prudent to exclude a significant part of these reserves from potential stable resources. At the end of December 2015, these booking entries amounted to 81 percent of the BEAC's total reserves, and were significantly larger than total reserves at the end of December 2016.

Having stable resources backing pooled reserves is a necessary, though not a sufficient, condition to help achieve adequate international reserves. Appropriate monetary policy is also required to avoid creating too much liquidity, which can lead to an increase in demand for foreign exchange. Specifically, government and bank deposits, which amounted to CFAF 2,019 billion at the end of 2016, were liquidities that their respective holders could use, and have used, to buy foreign exchange, hence drawing down international reserves. ${ }^{1}$ To reduce such risk, the BEAC could issue local currency sterilization instruments should monetary policy liquidity management considerations dictate the need. Such sterilization instruments, if issued regularly, can

${ }^{1}$ When the BEAC injects liquidity into CEMAC economies (lending directly to governments or to banks), beneficiaries may use this liquidity to purchase foreign exchange from the BEAC. By the end of 2016, governments' deposits had been drawn down significantly, but not depleted, as illustrated in the BEAC's balance sheet in Table 4. 
Table 4. BEAC: Simplified Balance Sheet, 2015-16

(Billions of CFA francs)

\begin{tabular}{|c|c|c|c|c|c|}
\hline Assets & 2015 & 2016 & Liabilities & 2015 & 2016 \\
\hline Totals & 9,388 & 6,959 & & 9,388 & 6,959 \\
\hline International reserves & 5,900 & 2,610 & Currency in circulation & 3,008 & 2,880 \\
\hline IMF & 309 & 380 & Governments' deposits & 1,921 & 923 \\
\hline Bank refinancing & 312 & 695 & Banks' deposits & 1,613 & 1,096 \\
\hline Loans to governments & 2,214 & 2,446 & Banks' required reserves & 1,071 & 448 \\
\hline Fixed assets & 283 & 434 & IMF and other deposits & 602 & 622 \\
\hline Other assets & 370 & 394 & Equity and long-term financing & 1,173 & 990 \\
\hline
\end{tabular}

also be considered stable resources for backing international reserves. So far, the BEAC has not adopted such a strategy, and this absence of sterilization of banks' excess reserves has clearly accelerated the decline in international reserves. Obviously, the BEAC may have decided for good reasons not to sterilize excess reserves, and even increase bank refinancing, but analyzing such reasons would go beyond the scope of this paper. What matters here is to emphasize the potential negative impact of such a policy on the level of international reserves.

To ensure the desired stable backing of international reserves, part of member states' deposits could also be transformed into long-term resources. This would enable the BEAC to fill the gap between the current amount of stable resources and the target level of reserves. Specifically, a portion of member states' deposits should be transformed into long-term resources (for example, blocked deposits or deposits incorporated into equity). Long-term resource backing for reserves above the target level (excess reserves allocated to NSFs) is not needed. In fact, a more flexible scheme, potentially similar to the framework currently applied to member states' deposits, could be envisaged.

CEMAC's Committee of Finance Ministers should endorse an investment strategy for international reserves. ${ }^{2}$ Ministerial endorsement is important to provide political support. The investment strategy should buttress the CFA franc's peg. To this end, the strategy should incorporate the general principles of security, liquidity, and returns on assets while ensuring the availability of liquid reserves up to the target level at all times. The strategy could involve a two-account framework in order of diminishing liquidity:

- Management Account, composed of an Operations Account (monetary portfolio) — that is, a mandatory amount deposited at the French Treasury for everyday transactions_-and a Liquidity Account (trading portfolio)

\footnotetext{
${ }^{2}$ However, committee members should not be involved in day-to-day investment management and decision making.
} 
used to meet all immediate cash flow requirements when deposits on the Operations Account are close to their mandatory minimum threshold (of 50 percent of total international reserves).

- Investment Account (investment portfolio)—used for reserves above the target level to meet less urgent cash flow needs. These reserves could be managed with a higher return objective, at the cost of lower liquidity and higher risk. This account would be made up of individual NSFs.

The size of the monetary and trading portfolios should always be at least equal to the target level of reserves. The two-account structure should include a mechanism to provide for the automatic replenishment of the most liquid portfolio with resources from the less liquid portfolio. ${ }^{3}$

The current strategic asset allocation of international reserves is not suitable for withstanding possible future adverse macroeconomic developments. The problem arises from the accounting treatment of the portion of reserves held in the BEAC's current investment portfolio, which is recorded as securities held to maturity. ${ }^{4}$ These securities do not meet the reserves liquidity requirement. Accordingly, ongoing discussions about a potential restructuring or liquidation of the portfolio should be concluded and the funding of this portfolio should be discontinued in favor of the portfolios suggested above. ${ }^{5}$ Meanwhile, the existing investment portfolio should not be part of target reserves. It is not a liquid portfolio and thus it should not be considered part of the international reserves available for immediate mobilization. The future streamlined investment portfolio should only hold excess reserves. It should be benchmarked against objectives for market, exchange, liquidity, and credit risks. The BEAC has already adopted strict rules for risk management and appropriate monitoring tools for implementing benchmarked portfolio management. These should prove useful if the recommended reserve management strategy is put in place.

The BEAC should design an appropriate strategic asset allocation to implement the recommended investment strategy. The current strategic asset allocation only partially fulfills this objective because a substantial portion of international reserves is held in long-term investments, thereby not fully meeting the liquidity objective. Good practice calls for an annual review of

\footnotetext{
${ }^{3}$ For example, through reallocation of coupon or principal payments in the monetary or trading portfolios. The BEAC prepared a draft proposal for a new reserve management framework, which is consistent with the proposal presented above (Politique générale de la gestion des réserves de change de la Banque des États de l'Afrique Centrale, General policy of foreign exchange reserve management at the BEAC, December 1, 2016).

${ }^{4} \mathrm{Of}$ the CFAF 5,441 billion of the BEAC's international reserves at the end of March 2016, CFAF 2,526 billion was invested in this portfolio.

${ }^{5}$ Because the market value of the investment portfolio has increased since the purchase of its components, partial or total liquidation of the investment portfolio would not generate book losses.
} 
the strategic asset allocation to keep up with developments in financial markets and in the BEAC's balance sheet.

Governments' contributions to the NSFs should be managed to yield appropriate returns. The investment strategy should result in appropriate remuneration of the government accounts backing international reserves, reflecting objectives and targeted returns on the corresponding assets. The BEAC should manage pooled reserves to make them financially attractive and thus reduce incentives for noncompliance with the surrender requirement. NSFs should receive higher remuneration than required reserves to make them financially attractive and to promote full compliance with the foreign exchange surrender requirement. A distinction between the accounts backing reserves up to target (for which remuneration is generally low or even nil, for instance, for equities) and the accounts contributing to NSFs (where remuneration and risk should be higher) is necessary. Remuneration of the latter accounts should be more attractive than that currently offered by the BEAC's Reserve Fund for Future Generations (Fonds de Réserve pour les Générations Futures). ${ }^{6}$

The BEAC should strengthen the capacity of its trading room to ensure that international reserves are managed dynamically. Given that best practices do not recommend immobilizing a substantial portion of international reserves in a buy-and-hold portfolio, dynamic management by the trading room is important. This in no way means the assumption of greater credit or market risks. On the contrary, more active reserve management would provide increased liquidity of investments and reduce market risk so that the potential liquidation of international reserves to meet foreign exchange requirements would not result in unanticipated losses. ${ }^{7}$

\footnotetext{
${ }^{6}$ By way of illustration, remuneration of the Fonds de Réserve pour les Générations Futures was 0.40 percent between July 2014 and March 2016, whereas the return on the BEAC's investment portfolio was 2.24 percent during the same period.

${ }^{7}$ This does not mean that book losses should be systematically avoided, because that objective could entail an opportunity cost that could not be justified by returns on international reserves.
} 


\section{Conclusion}

The BEAC's international reserves declined substantially between the onset of the oil-price shock in mid-2014 and the end of 2016, and medium-term prospects are for moderate levels of reserves. Based on a variety of analytical work, it is recommended that CEMAC authorities target five months' worth of imports of goods and services on a continuous basis for their pooled international reserves. This level of reserves is deemed appropriate for buttressing the common currency's peg and providing for a sustainable external position.

In this context, partial adherence to the reserve pooling requirement is a potential source of macroeconomic instability for CEMAC. The decline in reserves hindered the capacity of the BEAC to ensure sound management of the currency union. It is important that CEMAC member states reaffirm their intention to adhere more rigorously to the existing reserve pooling provisions. Such an announcement, followed by credible and demonstrable improvements in compliance, would help bolster confidence in the currency union and guard against possible instability. This announcement should be complemented by the publication of appropriate, high-frequency indicators to monitor developments (to provide transparency regarding public assets held abroad).

A new, two-tier international reserve management framework is proposed. The first-tier pooled reserves would continue to be managed by the BEAC under the central bank's own investment strategy and would require each member to surrender an agreed-upon portion of its foreign exchange assets to meet the pool's targeted level, as under current arrangements. The second tier would comprise NSFs, managed by the BEAC according to the guidance of each state, which would retain full ownership. NSFs may hold less-liquid and potentially higher-yielding financial assets than those kept in tier-one, pooled reserves. This framework would allow CEMAC member states to 
invest any excess reserves above the target level in financially attractive investment vehicles.

The new framework requires the adoption of novel investment and asset allocation strategies for reserve management. The framework entails defining clear rules on burden sharing to avoid free-rider issues if a member fails to contribute its required share to the common pool of reserves. It also requires specifying how the pooled international reserves would be replenished if they fall below the targeted threshold. The definition of such rules should be supported by appropriate fiscal rules and stances to ensure the Community's macroeconomic sustainability, building on existing on the regional convergence framework.

A first step could entail the adoption of the general principles of the proposed framework by CEMAC member states and the BEAC. Further negotiations would then be necessary to determine the operational aspects of the new framework. Among other actions, this approach would require possible legal amendments to CEMAC's agreements and the BEAC's charter, a clear definition of respective responsibilities between the BEAC and member countries, proper safeguards and enforceable obligations to abide by the new rules, and stronger reporting arrangements. Continued improvements in the BEAC's operations and increased transparency by member countries (in particular, concerning their foreign asset holdings) will be needed to pave the way for successful implementation of the proposed framework. 


\section{Annex 1: International Reserves in a Currency Union}

International reserves are liquid and freely usable assets, controlled by the monetary authorities, and used for mitigating the temporary effects of external shocks. According to the IMF's Balance of Payments Manual, international reserves are those external assets that are readily available to and controlled by monetary authorities for meeting balance of payments financing needs, for intervention in exchange markets to affect the currency exchange rate, and for other related purposes (such as maintaining confidence in the currency and providing a basis for foreign borrowing). This definition highlights the precautionary nature of international reserves for self-insurance purposes (Aizenman and Lee 2005). Accordingly, reserves help (1) meet transactional needs, such as import financing and exchange rate operations, (2) signal a country's ability to meet its financial needs, including its short-term debt obligations, (3) mitigate the effects of terms-of-trade shocks on output and consumption, and (4) cope with liquidity risks and the volatility of capital flows. Finally, countries with fixed exchange rate regimes use reserves to defend the peg (Wijnholds and Søndergaard 2007, 16). In sum, mitigating the impact of a shock, and thus reducing its cost for the economy, is the major benefit of holding reserves. Empirical evidence suggests that countries with higher reserves are better able to cope with external shocks (Crispolti and Tsibouris 2011).

Holding common reserves within a currency union potentially reduces each member country's costs and mitigates risks. An IMF study on the Eastern Caribbean Currency Union (Schipke, Cebotari, and Thacker 2013) finds that reserve pooling reduced individual members' costs through a single reserve management framework, the pooling of risks, and a reduction in the volatility of reserves. Managing a pool of reserves within a currency union yields economies of scale by lowering the overhead costs of individual members. Reserve pooling also serves as a buffer for seasonal variations in members' foreign exchange receipts (Schipke, Cebotari, and Thacker 2013, 383). In 
the absence of pooling, individual members would have to maintain a higher level of reserves, compared with their required contributions to the pool, if country-specific shocks within the union are less than perfectly correlated (Yéhoué 2005, 4).

Reserve accumulation, however, comes at a cost. From a financial perspective, the cost of accumulation is often calculated as the difference between the return on risk-free reserves and the interest rate of the country's long-term debt. ${ }^{1}$ This difference, usually negative-particularly in countries with limited access to international financial markets-could translate into quasi-fiscal losses if the term premium is large (Levy Yeyati 2010). At the same time, accumulating reserves may imply forgone investment and consumption, which is particularly relevant in countries with significant development needs (IMF 2011a; Dabla-Norris, Kim, and Shirono 2011). The forgone benefits from accumulating reserves rather than investing in sovereign wealth funds or financing development projects could also be considered a cost from a consumption-smoothing perspective.

${ }^{1}$ More specifically, the cost of accumulating reserves is the difference between the yield of the sterilization bond issued to purchase reserves (if issuing debt in domestic currency is possible) and the yield of the risk-free asset (Jeanne and Rancière 2006). 


\section{Annex 2: Does CEMAC Need Pooled International Reserves?}

France's guarantee of the CFA franc's peg requires the pooling of CEMAC's reserves. This is an institutional setup that reduces the risk to France in providing the guarantee. It could be argued that CEMAC does not need pooled reserves because, in principle, the convertibility guarantee allows the BEAC to acquire unlimited amounts of euros through its Operations Account at the French Treasury. The guarantee by the French Treasury-effectively an overdraft facility — should thus reduce the need for international reserves to a level sufficient to meet day-to-day operational constraints (Gulde and Tsangarides 2008, 118). This paper does not follow this logic. There is uncertainty about the capacity of the French Treasury, itself embedded in the wider rules of the euro area, to provide such a guarantee on a large scale for an indefinite period. Accordingly, this paper assumes that the sustainable, long-term safety of CEMAC requires that it be essentially "self-insured" to withstand various shocks. This approach, by diminishing the risk assumed by the French Treasury, buttresses the guarantee because it would then be used only for an exceptional shock.

CEMAC benefits in other ways from accumulating international reserves. First, reserve accumulation under the peg provides a nominal anchor. Second, it signals the sustainability of the regime itself given that it provides confidence in the authorities' commitment to support the value of the currency. ${ }^{1}$ Third, reserve pooling provides insurance to all members by allowing them to reduce potential losses in the event of adverse shocks (Iossifov and others 2009). Finally, reserve accumulation - through its counterpart, that is, fiscal buffers - may also facilitate consumption smoothing and ensure intergenera-

\footnotetext{
${ }^{1}$ Full convertibility enhances the credibility of the currency both within CEMAC and internationally, and facilitates access to global financial markets by lowering borrowing costs and attracting foreign direct investment.
} 
tional equity (IMF 2011a) because it opens up the possibility of implementing national stabilization funds.

Conversely, some studies argue that the benefits of reserve pooling are relatively low for most CEMAC members (Gulde and Tsangarides 2008, 102). External shocks tend to be highly correlated in CEMAC-consisting primarily of oil-price shocks-reducing the benefits of reserve pooling for individual members. Yéhoué $(2005,14)$ finds that pooling reserves does not smooth shocks in the CFA franc zone and therefore provides limited risk-sharing benefits. With little gain from reserve pooling, the surrender requirement, which constrains the use of foreign assets, could be perceived as burdensome, particularly by the large contributors to the pool. Pooling reserves and keeping a large part of such reserves on the BEAC's Operations Account at the French Treasury does not deliver equal gains to all member countriesthose with low or volatile reserves benefit the most (Williams, Polius, and Hazel 2001, 15). 


\section{Annex 3: CEMAC: Foreign Exchange Transaction and Payment Arrangements}

Administration of foreign exchange regulations is the responsibility of CEMAC Ministers of Finance, who may delegate all or a portion of their authority to the regional central bank (BEAC), the regional banking commission (COBAC), and licensed intermediaries. ${ }^{1}$ For example, authority is delegated to the latter to carry out transactions with the rest of the world. Intermediaries must verify the validity of transactions, collect statistics, and report these activities to the monetary authorities. The BEAC supervises foreign exchange regulations, evaluates hedging operations, reviews applications for approval for the opening of foreign exchange accounts by resident legal entities, and monitors the repatriation of export proceeds. The COBAC ensures that licensed intermediaries comply with relevant provisions of these regulations to prevent a weakening of CEMAC's banking system. Export proceeds collected in foreign currencies must be repatriated through the domiciling bank and surrendered to the BEAC within 30 days of collection.

Some specific rules are as follows:

- The exchange regulations do not limit access to foreign exchange for the payment of merchandise imports.

- There are no exchange restrictions on service-related transactions. Payments for such transactions are subject to the same requirements as apply to merchandise imports.

- There are no restrictions on most capital flows between CEMAC and non-CEMAC countries, provided they comply with the laws and regulations prohibiting drug financing and trafficking.

- Regarding capital inflows, certain loans and direct investments are subject to administrative controls.

${ }^{1}$ This annex is based on IMF, Annual Report on Exchange Arrangements and Exchange Restrictions, 2015. 
- Regarding capital outflows, CEMAC residents may purchase bonds, securities, and collective investment securities abroad, subject to BEAC and national ministry of finance approval when the total outstanding debt of the nonresident issuer exceeds CFAF 100 million (about US\$180,000). Banks verify and make payments for such transactions. Subject to prior approval by the Commission for Monitoring the Central African Money Market (COSUMAF), the regulations governing the management of a collective investment fund and the articles of incorporation of an open-ended investment company allow purchases and sales of securities on markets outside CEMAC. 


\title{
Annex 4: Surrender Requirements in Currency Unions
}

\begin{abstract}
Currency unions outside the CFA franc zone do not require member states to surrender all their foreign exchange assets to the common central bank. ${ }^{1}$ The requirement to centralize all foreign exchange assets at the common central bank does not exist in the ECCU, although an export proceeds repatriation requirement prevails for residents of three member states, namely Dominica, St. Kitts and Nevis, and St. Vincent and the Grenadines. Neither repatriation nor surrender requirements apply in the member states of the euro area, where the participating national central banks provide the European Central Bank with only part of their international reserves (Annex Table 4.1).2
\end{abstract}

\footnotetext{
${ }^{1}$ In fact, the surrender requirement to the Central Bank of West African States (but not to the BEAC) applies only to foreign exchange earnings from current account, but not from capital account transactions. Foreign exchange earnings from capital account transactions are to be surrendered to authorized dealers (IMF, Annual Report on Exchange Rate Arrangements and Exchange Rate Restriction, 2015).

${ }^{2}$ In case of need, the European Central Bank may, however, call on up to $€ 50$ billion in additional international reserves from the national central banks (Articles 28 to 31 of the Statutes of the European System of Central Banks and of the European Central Bank). It is important to note that the euro is a freely floating currency, thus there is no peg to defend-accordingly, the comparison with CEMAC is only partially relevant.
} 
Annex Table 4.1. Repatriation and Surrender Requirements in Currency Unions

\begin{tabular}{|c|c|c|c|c|c|c|c|c|}
\hline & \multirow{2}{*}{$\begin{array}{c}\text { CEMAC } \\
\text { Member } \\
\text { States }\end{array}$} & \multirow{2}{*}{$\begin{array}{l}\text { WAEMU } \\
\text { Member } \\
\text { States }\end{array}$} & \multirow{2}{*}{$\begin{array}{l}\text { Euro Area } \\
\text { Member } \\
\text { States }\end{array}$} & \multicolumn{5}{|c|}{ ECCU } \\
\hline & & & & $\begin{array}{c}\text { Antigua and } \\
\text { Barbuda }\end{array}$ & Dominica & $\begin{array}{c}\text { St. Kitts } \\
\text { and Nevis }\end{array}$ & $\begin{array}{c}\text { St. Vincent } \\
\text { and the Grenadines }\end{array}$ & St. Lucia \\
\hline \multicolumn{9}{|l|}{ Export Proceeds } \\
\hline Repatriation requirements & Yes $^{1}$ & Yes $^{1}$ & No & n.a. & Yes & Yes & Yes & No \\
\hline Surrender requirements & Yes & Yes & No & No & Yes & Yes & Yes & No \\
\hline To the central bank & $Y_{e s}^{2}$ & $Y_{e s^{2}}$ & No & No & No & No & No & No \\
\hline To authorized dealers & No & No & No & No & Yes $^{3}$ & No & Yes $^{3}$ & No \\
\hline \multicolumn{9}{|c|}{ Earnings from capital transactions } \\
\hline Repatriation requirements & Yes & Yes & No & No & No & n.a. & No & No \\
\hline Surrender requirements & Yes & Yes & No & No & No & n.a. & No & No \\
\hline To the central bank & Yes & No & No & No & No & n.a. & No & No \\
\hline To authorized dealers & No & Yes & No & No & No & n.a. & No & No \\
\hline
\end{tabular}

Exchange Rate Arrangements and Exchange Restrictions, 2015.

${ }^{1}$ All export-related transactions must be reported to the appropriate administrative authorities, and all thos exceeding CFAF 5 million must be domiciled at a licenced CEMAC / WAEMU bank. Export proceeds originating in non-CEMAC or WAEMU member states must be collected and repatriated within 30 days of the date stipulated in the contract, through the domiciling bank, with the BEAC acting as intermediary. Export proceeds collected in foreign currencies must be surrendered to the BEAC / BCEA0 within 30 days of collection.

${ }^{3}$ All export-related transactions must be surrendered within six months of receipt, but this regulation is inoperative.

${ }^{4}$ Export proceeds must be converted into Eastern Caribbean dollars and deposited in an ECCB account, unless the exporter has a foreign exchange account to which the proceeds may be credited. 


\section{Annex 5: BEAC's International Reserve Management Framework}

The pooling of foreign assets is a cornerstone of CEMAC. According to CEMAC's monetary cooperation arrangement with France, all member countries are required to surrender their foreign assets to the BEAC. For monitoring purposes, the BEAC is requested to calculate foreign assets imputed to each of the member countries.

The French guarantee of the CFA franc's peg may be construed as insurance in the event of adverse temporary shocks. It does not eliminate the need for CEMAC member states to take appropriate corrective measures and hold adequate reserves to sustain the peg. In exchange for the guarantee, the $\mathrm{BEAC}$ is required to deposit at least half of its net foreign assets in its Operations Account at the French Treasury in euros. The French Treasury guarantees the positive balance of the Operations Account against the risk of a depreciation of the euro vis-à-vis the SDR (special drawing right).

The BEAC may invest its foreign currency assets not deposited with the French Treasury in financial assets suitable for international reserves. Following the December 2006 amendment of Article 11 of the BEAC's charter, foreign currency assets not deposited with the French Treasury may be invested in (1) deposits with financial institutions with a minimum A+ rating, (2) debt securities issued by public or private entities with a minimum AA rating, (3) debt securities issued by international financial institutions with a minimum AA rating, (4) debt securities guaranteed by countries with a minimum AA rating, and (5) related hedging transactions. If foreign assets are backed by government deposits of more than one year with the BEAC, they are excluded from the basis of the calculation of the share to be deposited with the French Treasury. The BEAC may outsource the management of a portion of these reserves to external specialized institutions. The strategic benchmarks (horizon, return, risk) for the management of all investments are defined by an internal committee at the BEAC. In the wake of the 2006 
reform, the BEAC has started to invest in long-term bonds held to maturity, issued by public or private entities with a minimum AA rating. ${ }^{1}$ Although the investment opportunities created by the reform appear appropriate for a liquid portfolio, they are more restrictive than those used by other central banks for long-term investment portfolios.

Since 2006, the BEAC has been offering three interest-bearing facilities to member countries with different maturities: (1) Conventional Special Deposits (CSDs), (2) Budget Revenue Stabilization Mechanism (BRSM), and (3) Reserve Fund for Future Generations (RFFG). These facilities are remunerated at rates set by the Monetary Policy Committee, based on the remuneration of the Operations Accounts. Interest rates paid by the BEAC on member states' local currency deposits may be negative in real terms. In July 2014, the annual interest rates on CSDs and deposits in the BRSM and the RFFG were 0.00 percent, 0.05 percent, and 0.40 percent, respectively, below CEMAC's annual inflation rate.

\footnotetext{
${ }^{1}$ To manage its reserves not held at the French Treasury, the BEAC has set up a trading room that operates under the guidance of the Monetary Policy, Strategy, and Operations Committees (Laurens, Coumba, and Alain 2009).
} 


\section{Annex 6: International Reserve Adequacy in Currency Unions}

Reserve adequacy should be assessed against all resources available with which to mitigate shocks, given external vulnerabilities. Among other factors, adequacy depends on a country's monetary and exchange rate arrangements; its macroeconomic policies and prudential practices; the size, nature, and frequency of its balance of payments needs; and the level of its indebtedness. In principle, the adequacy of reserves is assessed by their capacity to minimize the effects of external shocks on the domestic economy. In practice, other types of foreign assets or contingent credits have been used to complement reserves for mitigating the effects of shocks. ${ }^{1}$ However, the 2008 global financial crisis demonstrated that not all assets held in reserves are readily available in turbulent times.

An important issue for reserve pooling concerns "required" versus "excess" reserves. It is generally good policy for a country, and by extension for a currency union, to hold an adequate amount of international reserves to protect against external shocks. The adequate level of reserves, often called required reserves, has been the subject of much debate in the economic literature. Excess reserves are reserves beyond required reserves, whose purpose goes beyond temporary self-protection.

Traditional metrics and cost-benefit models are typically used to assess reserve adequacy. Traditional metrics are benchmarks focusing on selected aspects of external vulnerability. For the most part, these benchmarks reflect self-insurance or precautionary motives for reserve accumulation, and abstract from policies that may lead to output losses, the need to address natural disasters or emergencies, and wealth aspects (Baker and Nxumalo 2012). The validity of the various benchmarks depends on, among other factors, trade

\footnotetext{
${ }^{1}$ For instance, access to financing from the IMF or other lenders could provide contingent protection.
} 
Annex Table 6.1. Selected Reserve Adequacy Benchmarks

\begin{tabular}{|c|c|c|c|}
\hline Ratio & Benchmark & Vulnerability & Description \\
\hline $\begin{array}{l}\text { Gross international reserves (GIR) to } \\
\text { prospective imports of goods and nonfactor } \\
\text { services }\end{array}$ & $\begin{array}{l}\text { Three months for } \\
\text { low-income countries; } \\
\text { five months and more } \\
\text { for fixed peg currency } \\
\text { unions }\end{array}$ & Current account & $\begin{array}{l}\text { Relevant for low-income countries and } \\
\text { countries without access to international } \\
\text { capital markets. The benchmark can } \\
\text { be made country specific, depending } \\
\text { on past and expected future volatility of } \\
\text { current account flows (for example, high } \\
\text { concentration of exports). }\end{array}$ \\
\hline GIR to broad money & No uniform benchmark & Capital flight & $\begin{array}{l}\text { Relevant for countries whose financial } \\
\text { systems are subject to rapid shifts in } \\
\text { market sentiment, often associated with an } \\
\text { overvalued currency, a weak banking system, } \\
\text { or unpredictable shifts in asset preferences. }\end{array}$ \\
\hline $\begin{array}{l}\text { GIR to short-term external debt (based on } \\
\text { remaining maturity) }\end{array}$ & 100 percent & Liquidity & $\begin{array}{l}\text { Relevant for countries with market access, } \\
\text { substantial private external borrowing, or } \\
\text { large public debt service payments. }\end{array}$ \\
\hline $\begin{array}{l}\text { GIR to short-term external debt plus short- } \\
\text { term foreign-currency-denominated public } \\
\text { domestic debt (based on remaining maturity) }\end{array}$ & No uniform benchmark & Liquidity & $\begin{array}{l}\text { Relevant for countries in the category } \\
\text { above and those with a large fraction of } \\
\text { their domestic debt denominated in foreign } \\
\text { currency. }\end{array}$ \\
\hline $\begin{array}{l}\text { GIR to short-term external debt plus current } \\
\text { account deficit }\end{array}$ & No uniform benchmark & $\begin{array}{l}\text { Current account } \\
\text { and liquidity }\end{array}$ & $\begin{array}{l}\text { Relevant for countries with large current } \\
\text { account deficits and limited international } \\
\text { capital market access. }\end{array}$ \\
\hline $\begin{array}{l}\text { Consolidated banking sector reserves to } \\
\text { short-term debt (based on remaining maturity) } \\
\text { plus residents' foreign exchange deposits }\end{array}$ & No uniform benchmark & Liquidity & Relevant for dollarized economies. \\
\hline
\end{tabular}

openness, the degree of international capital mobility, access to international financial markets, and liquidity risks. The assessment of reserve adequacy may rely on stand-alone benchmarks or on composite indicators using several traditional metrics (Annex Table 6.1; Baker and Nxumalo 2012; IMF 2011a). Three sets of metrics are commonly used to assess international reserve adequacy: (1) current account norms (such as reserve coverage in months of imports of goods and services), (2) capital account norms (such as the ratio of reserves to short-term debt by remaining maturity), and (3) monetary norms (such as the ratio of reserves to broad or base money). These metrics, although commonly used, lack robust theoretical and empirical foundations.

Cost-benefit models may also be used to estimate reserve adequacy. These models estimate the extent to which a given level of reserves is sufficient to smooth the required adjustment during severe shocks. The cost of holding reserves is typically measured by forgone alternative investment opportunities. These models provide a lower bound of the adequate level of reserves given the assumption of risk neutrality. To assess reserve adequacy, actual reserve holdings are compared with model-based adequate reserve estimates. ${ }^{2}$

\footnotetext{
${ }^{2}$ Dabla-Norris, Kim, and Shirono (2011) for low-income countries; Gijón, Furceri, and Crivelli (2012) for Algeria (a large hydrocarbon exporter); and Jeanne and Rancière (2006) for emerging markets.
} 


\section{Annex 7: International Reserves and Fiscal Policy}

The fiscal channel can play a critical role in international reserve accumulation. International reserves are accumulated as a result of balance of payment surpluses. The external current account balance is heavily influenced by the government's saving-to-investment balance, equivalent to the overall fiscal balance. Thus, governments' fiscal rules to deal with the volatility of resource revenue potentially have important impacts on international reserve accumulation. At the same time, the size of this impact also depends on governments' "below-the-line" operations, which reflect their choices between holding external vs. domestic assets and contracting external vs. domestic debt. ${ }^{1}$

It is critical to ensure consistency between fiscal policy and international reserve accumulation. Two issues need to be considered: (1) the design of the fiscal framework and associated targets, and (2) the links between the fiscal position and stabilization savings fund flows.

- Fiscal policy should support the exchange rate arrangement by contributing appropriately to required reserves. Resource-exporting countries can use various options to anchor their fiscal policy, including by using either non-resource balance rules or resource-price-based rules. ${ }^{2}$ Fiscal targets need to be consistent with required reserve coverage ratios, based on projected resource revenue. If resource revenue is higher than projected, excess reserves are accrued, which can support stabilization objectives or scaled-up spending plans.

\footnotetext{
'This annex limits its focus to issues related to governments' above-the-line operations. Accordingly, it does not consider issues related to governments' portfolio choices.

${ }^{2}$ IMF (2012b) provides a more detailed discussion of fiscal anchor options for resource-rich countries. Overall fiscal balance rules are not well-suited to resource-rich countries except for complementary overall balance floors aimed at triggering a fiscal adjustment in response to sharply lower resource prices. Such rules can be used as a safeguard to prevent international reserves from falling below a certain threshold.
} 
- Flows into stabilization funds should be generated principally from fiscal surpluses. This is not obvious, because there is ample empirical evidence worldwide of rigid inflow rules into fiscal funds-independent of the fiscal position-which tend to be unsustainable (IMF 2007a). In fact, rigid accumulation rules (for example, based on predetermined shares of oil revenue) may lead to situations in which the government is forced to borrow to meet its savings rules.

Fiscal savings can be used toward short-term stabilization and long-term wealth accumulation. Countries with short resource horizons tend to give more weight to ensuring sufficient long-term wealth after the resources are depleted. Countries with long-term resource horizons tend to focus on smoothing short-term volatilities. A stabilization fund should protect the execution of the government's budget, as originally planned, despite an adverse shock. Accordingly, a value-at-risk analysis can provide insights into the appropriate size of such a fund; any shock-induced revenue shortfall would be compensated by drawing from the stabilization fund to avoid disruptive expenditure cuts. Stabilization funds can thus be useful tools for macro-fiscal management in resource-rich countries, but should not be confused with fiscal policy, nor should the funds' inflow-outflow rules be confused with fiscal rules.

Fiscal anchoring based on non-resource balance rules is particularly relevant when concerns about resource exhaustibility and long-term fiscal sustainability prevail. Such anchoring can take several forms, depending on specific country characteristics.

- Bird-in-hand framework. This rule requires countries to expend all natural-resource-related revenue to accumulate financial assets, and use only the yield from the accumulated financial assets for expenditure. This approach is very conservative (that is, highly risk averse) and may be appropriate for countries in an advanced stage of development and with a short resource horizon. It is also restrictive in the initial years of resource exploitation when the yield is low. Norway's sovereign wealth fund is based on this approach.

- Permanent income hypothesis (PIH) framework. This rule sustains a constant consumption flow over current and future generations. This approach is risk averse and may be appropriate for countries with no pressing development needs. The PIH approach may, however, be too restrictive for low-to-middle-income countries with significant infrastructure gaps because it does not allow for increases in public investment spending above baseline levels.

- Modified PIH framework. This rule deviates from the traditional PIH approach by allowing an initial period of front-loading of capital expendi- 
ture (that is, investment scaling up), followed by a scaling back of spending to preserve long-term savings (net financial wealth) at the PIH level. Although still conservative, this rule nevertheless allows immediate development needs to be addressed. Timor-Leste uses this approach.

Resource-price-based rules rely on smoothed resource revenue and fiscal targets to delink expenditure from resource-price volatility. In such a framework, expenditure levels are determined based on smoothed resource revenue for a given fiscal target. The resource revenue is projected based on smoothed projections of resource prices, which are obtained as a moving average of past, present, and future prices; the respective weights of prices depend on the desired degree of smoothing. Resource-price-based rules are designed to mitigate price volatility and allow the fiscal balance to adjust to revenue variations. Moreover, they are an appropriate instrument for the creation of fiscal buffers. Commodity reference prices can be calculated by formulas or by an independent committee (as in Chile). ${ }^{3}$ Ghana uses a seven-year moving average that includes three projected years. Weighting past prices more heavily may lead to smoother revenue projections, thus less-variable expenditure envelopes, but stymies market signals. Placing higher weights on future prices allows more responsiveness to price trends, but may lead to more volatile revenue projections and expenditure envelopes.

When concerns about absorptive capacity of expenditure are particularly prevalent, an expenditure-growth rule can be added to limit the growth of government spending. This rule limits the growth of government spending in nominal or real terms, or as a percentage of non-resource GDP. It helps address the procyclicality of fiscal policy and limits expenditure in line with absorptive capacity (which may be needed to ensure efficiency of expenditure, or to deal with overheating or large current account deficits). Expenditure rules are a useful and visible support to maintaining prudent fiscal policy. Peru and Mongolia use expenditure-growth rules.

An important issue when designing a fiscal framework is the choice of the fiscal indicator (or anchor) around which any rule or guideline will be framed:

- Overall fiscal balance. Although commonly used, this indicator can be procyclical in resource-dependent countries, and does not allow for an analysis of fiscal sustainability when natural resources are gradually depleted. However, it can provide an indication of the change in net wealth and gross financing needs when resource revenue declines.

\footnotetext{
3In Chile, a fiscal rule was introduced in 2000 limiting spending to an estimate of the trend of government revenue, based on trend estimates of GDP and copper prices, with a 1 percent of GDP target for the structural balance. An independent committee was set up to determine the copper prices to be used for budget purposes.
} 
- Non-resource primary balance (NRPB). The NRPB is a key indicator of the fiscal stance in resource-dependent countries (that is, it denotes whether the fiscal policy is procyclical or countercyclical). It can help delink fiscal policy from revenue volatility, thus allowing expenditures to be smoothed for development needs and absorption capacity, and can be compared with a benchmark for long-term fiscal sustainability. This indicator can be anchored either by a PIH calculation or by other macroeconomic concerns. However, an NRPB rule can create the misperception of a worsening fiscal situation when countries expand their capital budgets in response to rising resource revenues, even when the scaling up of investment is consistent with macroeconomic stability.

- Structural primary balance. This is the primary balance in which revenue is stripped of its cyclical component by relying on a smoothed resource price (that is, using an average of past, present, and future resource prices). This indicator is considered more appropriate for countries with relatively long resource horizons. A fiscal rule based on this indicator will reduce the transmission of externally driven resource-price volatility. It will also be more intuitive to policymakers than an NRPB rule, which may exclude a very large part of fiscal revenues and economic activity from the fiscal target. In addition, it can support solvency through prudent forecasting of structural revenues by deliberately under-projecting the structural resource price.

- Basic fiscal balance. Previously used by CEMAC for its fiscal convergence criterion, the basic fiscal balance has the advantage of measuring direct fiscal effort by country authorities. ${ }^{4}$ However, it does not provide a strong anchor for assessing the fiscal stance and ensuring long-term fiscal sustainability because externally financed capital expenditure, which is excluded from this indicator, has an impact on aggregate demand and can contribute to rising external debt. It can also mask procyclicality of fiscal policy.

For CEMAC, the trade-offs to be considered to strengthen the fiscal surveillance framework need to be weighed carefully, and more analysis is needed before choosing the most appropriate fiscal rule. ${ }^{5}$ On balance, however, a structural primary balance rule based on hydrocarbon price smoothing would seem a particularly appropriate option. This rule would help address issues of volatility and fiscal procyclicality, and it could be applied more homogeneously across the Community than a non-resource primary balance rule. It would, nevertheless, need to be calibrated at the individual country level in a way that makes it suitable to country-specific needs, including to ensure

\footnotetext{
${ }^{4}$ The supplementary fiscal indicators of basic structural and non-oil basic fiscal balances also exclude foreign-financed capital spending and therefore suffer from some of the same weaknesses as the basic fiscal balance. A new CEMAC convergence framework entered into effect in January 2018. It uses the overall fiscal balance as the new fiscal anchor.

${ }^{5}$ See Annex 4 of IMF (2013b) for a detailed discussion on suitable fiscal frameworks for CEMAC.
} 
long-term sustainability and the stability of the monetary union. For example, setting a zero or slightly positive structural primary balance target for CEMAC as a whole would likely ensure the stability of the Community; however, this target could appear to be too restrictive for countries with large oil wealth and unmet development needs.

Objectives for stabilization funds should be set to complement any fiscal rule in CEMAC, to provide a sufficient buffer against potentially large, negative oil-price and revenue shocks with a high degree of confidence. The optimal size of stabilization funds can be estimated in various ways, including benchmarking and value-at-risk modeling. Calculations for CEMAC countries based on the more rigorous approach of value-at-risk analysis, coupled with a structural primary balance rule, indicate that member countries would need to build significantly larger fiscal savings than what they currently have. ${ }^{6}$ The development of appropriate investment vehicles for such savings, as well as proper governance within the monetary union, is critical to support this objective.

${ }^{6}$ See IMF (2014b) for an estimate of optimal fiscal stabilization funds for CEMAC. 
This page intentionally left blank

CInternational Monetary Fund. Not for Redistribution 


\section{Bibliography}

Agbor, Julius. 2012. "The Future of the CEMAC CFA Franc." Brookings Institution, Washington, DC.

Aizenman, Joshua, and Jaewoo Lee. 2005. "International Reserves: Precautionary versus Mercantilist Views, Theory and Evidence.” IMF Working Paper 05/198, International Monetary Fund, Washington, DC.

Avom, Désiré. 2012. "Les Fonds Souverains en Union Monétaire: Quels Enseignements pour la BEAC?" Presentation to a seminar on Sovereign Wealth Funds organized by the Bank of Central African States, Libreville, Gabon, August.

Bagattini, Yudi G. 2011. "The Political Economy of Stabilisation Funds: Measuring Their Success in Resource-Dependent Countries.” IDS Working Papers 2011 (356): 1-60.

Baker, Carol and M. Nxumalo. 2012. "Assessing Reserve Adequacy of the Oil-Rich CEMAC Region: What Can We Learn from the 2008-09 Oil Price Shock?” IMF Working Paper, International Monetary Fund, Washington, DC. Unpublished.

Banque Centrale des États de l'Afrique Centrale (BEAC). 1972. "Convention de Coopération Monétaire entre les États Membres de la BEAC et la République Française.” Unpublished, November.

—. 2007. "Convention de Compte d'Opérations de la Banque des États de l'Afrique Centrale." January.

. 2010. "Statuts de la Banque des États de l'Afrique Centrale.” October.

2012. "Problématique de Centralisation à la BEAC des Avoirs en Devises des États Membres de la CEMAC.” August. Unpublished. 
Barnichon, Régis. 2008. "International Reserves and Self-Insurance against External Shocks.” IMF Working Paper 08/149, International Monetary Fund, Washington, DC.

Baunsgaard, Thomas, Mauricio Villafuerte, Marcos Poplawski-Ribeiro, and Christine Richmond. 2012. "Fiscal Framework for Resource-Rich Developing Countries." IMF Staff Discussion Note 12/04, International Monetary Fund, Washington, DC.

Collier, Paul, Frederick van der Ploeg, Michael Spence, and Anthony J. Venables. 2010. "Managing Resource Revenues in Developing Countries." IMF Staff Papers 57 (1): 84-118.

Comité Mixte sur le Rapatriement des Avoirs en Devises des États Membres de la CEMAC. 2012a. "Amélioration du Dispositif Existant et Proposition d'un Nouveau Type de Placement au Profit des Etats." Unpublished.

. 2012b. "Détermination du Niveau Adéquat des Réserves de Change de la BEAC et Proposition de Répartition entre Portefeuille d'Investissement et de Liquidité." Unpublished.

. 2012c. "Dispositif de Surveillance du Rapatriement des Avoirs en Devises des États de la CEMAC.” Unpublished.

- 2012d. "Réflexion à Mener sur la Vulgarisation de la Réglementation des Changes de la CEMAC." Unpublished.

Communauté Économique et Monétaire de l'Afrique Centrale (CEMAC). 2008. "Convention Régissant l'Union Monétaire de l'Afrique Centrale (UMAC).” June.

Coulibaly, Brahima. 2009. "Currency Unions and Currency Crises: An Empirical Assessment." Journal of International Economics and Finance 14 (3): 199-221.

Crispolti, Valerio, and George Tsibouris. 2012. "International Reserves in Low Income Countries: Have They Served as Buffers?” IMF Working Paper 12/07, International Monetary Fund, Washington, DC.

Dabla-Norris, Era, Jun Il Kim, and Kazuko Shirono. 2011. "Optimal Precautionary Reserves for Low-Income Countries: A Cost-Benefit Analysis." IMF Working Paper 11/249, International Monetary Fund, Washington, DC.

Dehesa, Mario, Emilio Pineda, and Samuel Wendell. 2009. "Optimal Reserves in the Eastern Caribbean Currency Union.” IMF Working Paper 09/77, International Monetary Fund, Washington, DC.

Deléchat, Corinne, and Jan Kees Martijn. 2008. "Reserve Adequacy in the CFA Franc Zone." In The CFA Franc Zone: Common Currency, Uncommon Challenges, edited by Anne-Marie Gulde and Charalambos Tsangarides. International Monetary Fund, Washington, DC. 
Deléchat, Corinne, Gustavo Ramirez, and Romain Veyrune. 2008. "Monetary Policy in a Currency Union? The Case of CEMAC." In The CFA Franc Zone: Common Currency, Uncommon Challenges, edited by Anne-Marie Gulde and Charalambos Tsangarides. Washington, DC: International Monetary Fund.

Drummond, Paulo. 2007. "Implications of Oil Inflows for Savings and Reserve Management in the CEMAC." IMF Working Paper 07/243, International Monetary Fund, Washington, DC.

, and Dhasmana Anubba. 2008. "Foreign Reserve Adequacy in Sub-Saharan Africa.” IMF Working Paper 08/150, International Monetary Fund, Washington, DC.

Gijón, José, Davide Furceri, and Ernesto Crivelli. 2012. "Algeria: Assessing Reserve Adequacy." Selected Issues Paper in IMF Country Report 12/22, International Monetary Fund, Washington, DC.

Gulde, Anne-Marie, and Charalambos Tsangarides, editors. 2008. The CFA Franc Zone: Common Currency, Uncommon Challenges. International Monetary Fund, Washington, DC.

Independent Evaluation Office of the IMF. 2012. "International Reserves; IMF Concerns and Country Perspective." Washington, DC, August.

International Monetary Fund (IMF). 2005a. "Central African Economic and Monetary Community: Selected Issues.” IMF Country Report 05/390, Washington, DC.

. 2005b. "Central African Economic and Monetary Community: Staff Report on Common Policies of Member Countries." IMF Country Report 05/403, Washington, DC.

2006a. "Central African Economic and Monetary Community: Financial System Stability Assessment.” IMF Country Report 06/321, Washington, DC.

- 2006b. "Central African Economic and Monetary Community: Staff Report on Common Policies of Member Countries; Staff Statement; Public Information Notice on the Executive Board Discussion; and Statement by the Executive Director for the Central African Economic and Monetary Community.” IMF Country Report 06/317, Washington, DC.

. 2007. "Managing the Oil Revenue Boom: The Role of Fiscal Institutions.” IMF Occasional Paper 260, Washington, DC.

. 2011a. "Assessing Reserve Adequacy." Staff Report prepared by the Monetary and Capital Markets, Research, and Strategy, Policy, and Review Departments, Washington, DC. 
2011b. "Central African Economic and Monetary Community: Staff Report on Common Policies of Member Countries; Public Information Notice on the Executive Board Discussion; and Statement by the Executive Director for the Central African Economic and Monetary Community." IMF Country Report 11/329, Washington, DC.

. 2012a. "Central African Economic and Monetary Community: Staff Report on Common Policies of Member Countries; Public Information Notice on the Executive Board Discussion; and Statement by the Executive Director for the Central African Economic and Monetary Community." IMF Country Report 12/244, Washington, DC.

_ 2012b. "Fiscal Frameworks for Resource-Rich Developing Countries." IMF Staff Discussion Note 12/04, Washington, DC.

. 2012c. "Macroeconomic Policy Frameworks for Resource-Rich Developing Countries.” IMF Policy Paper, Washington, DC.

2012d. "Macroeconomic Policy Frameworks for Resource-Rich Developing Countries—Background Paper 1-Supplement 1.” IMF Policy Paper, Washington, DC.

_. 2013a. "Assessing Reserve Adequacy-Further Considerations." Staff Report Prepared by the Strategy, Policy, and Review Department, Washington, DC.

— 2013b. "Central African Economic and Monetary Community (CEMAC): Staff Report on Common Policies for Member Countries." IMF Country Report 13/322, Washington, DC.

. 2014a. "Central African Economic and Monetary Community (CEMAC): Selected Issues.” IMF Country Report 14/305, Washington, DC.

2014b. "Sovereign Asset-Liability Management-Guidance for Resource-Rich Countries.” IMF Policy Paper, Washington, DC.

2015. "Central African Economic and Monetary Community (CEMAC): Staff Report on Common Policies and Challenges of Member Countries." IMF Country Report 15/222, Washington, DC.

2016. "Central African Economic and Monetary Community (CEMAC); Common Policies of Member Countries-Press Release; Staff Report; and Statement by the Executive Director." IMF Country Report 16/277, Washington, DC.

2017. "Gabon Request for an Extended Arrangement under the Extended Fund Facility-Press Release; Staff Report; and Statement by the Executive Director." IMF Country Report 17/205, Washington, DC. 
Iossifov, P., N. Kinoshita, M. Takebe, R. York, and Z. Zhan. 2009. "Improving Surveillance across the CEMAC Region.” IMF Working Paper 09/260, International Monetary Fund, Washington, DC.

Jeanne, Olivier, and Romain Rancière. 2006. "The Optimal Level of International Reserves for Emerging Market Countries: Formulas and Applications." IMF Working Paper 06/29, International Monetary Fund, Washington, DC.

Laurens, Bernard, and Alexander Attié. 2007. "Bank of Central African States - Foreign Asset Management: Short and Medium-Term Issues.” Technical Assistance Report, Monetary and Capital Markets Departments, International Monetary Fund, Washington, DC. Unpublished.

Laurens, Bernard, Gueye Coumba, and Durré Alain. 2009. "Bank of Central African States - Reserve Management, Research, and Regional Public Debt Market.” Technical Assistance Report, Monetary and Capital Markets Departments, International Monetary Fund, Washington, DC. Unpublished.

Len, Stephen. 2010. "Sovereign Wealth Fund Investment Strategies: Complementing Central Bank Investment Strategies.” In Economics of Sovereign Wealth Funds - Issues for Policymakers, edited by Udaibir S. Das, Mazarei Adnan, and Han van der Hoorn. International Monetary Fund, Washington, DC.

Levy Yeyati, Eduardo. 2010. "What Drives Reserve Accumulation (and at What Cost)?” VOX website. http://www.voxeu.org/article/what-drives -reserve-accumulation-and-what-cost.

Mpatswe, Gaston, Sampawende Tapsoba, and Robert York. 2012. "The Cyclicality of Fiscal Policies in the CEMAC Region." In Oil Wealth in Central Africa: Policies for Inclusive Growth, edited by Bernardin Akitoby and Sharmini Coorey. International Monetary Fund, Washington, DC.

Mwase, Nkunde. 2012. "How Much Should I Hold? Reserve Adequacy in Emerging Markets and Small Islands." IMF Working Paper 12/205, International Monetary Fund, Washington, DC.

Schipke, Alfred. 2012. "Snapshot of Another Monetary Union - The Eastern Caribbean Currency Union.” Finance and Development 49 (1).

Schipke, Alfred, Aliona Cebotari, and Nita Thacker. 2013. Eastern Caribbean Economic and Currency Union: Macroeconomics and Financial Systems. International Monetary Fund, Washington, DC.

van Beek, Frits, Jose Roberto Rosales, Mayra Zermeno, Ruby Randall, and Jorge Shepherd. 2000. "The Eastern Caribbean Currency Union: Institu- 
tions, Performance, and Policy Issues.” IMF Occasional Paper 195, International Monetary Fund, Washington, DC.

Wiegand, Johannes. 2004. "Fiscal Surveillance in a Petro Zone: The Case of the CEMAC.” IMF Working Paper 04/8, International Monetary Fund, Washington, DC.

Wijnholds, J. Onno, and Lars Søndergaard. 2007. "Reserve Accumulation: Objective or By-Product?" European Central Bank Occasional Paper 73, European Central Bank, Frankfurt, Germany.

Williams, Oral, Tracy Polius, and Selvon Hazel. 2001. "Reserve Pooling in the Eastern Caribbean Currency Union and the CFA Franc Zone: A Comparative Analysis." IMF Working Paper 01/104, International Monetary Fund, Washington, DC.

Yéhoué, Étienne B. 2005. "International Risk Sharing and Currency Unions: The CFA Franc Zone.” IMF Working Paper 05/95, International Monetary Fund, Washington, DC. 